\title{
A snow-transport model for complex terrain
}

\author{
Glen E. Liston, ${ }^{1}$ Matthew Sturm ${ }^{2}$ \\ ${ }^{1}$ Department of Atmospheric Science, Colorado State University, Fort Collins, Colorado 80523, U.S.A. \\ ${ }^{2}$ U.S. Army Cold Regions Research and Engineering Laboratory, Fort Wainwright, Alaska 99703-0170, U.S.A.
}

\begin{abstract}
As part of the winter environment in middle- and high-latitude regions, the interactions between wind, vegetation, topography and snowfall produce snow covers of non-uniform depth and snow water-equivalent distribution. A physically based numerical snow-transport model (SnowTran-3D) is developed and used to simulate this threedimensional snow-depth evolution over topographically variable terrain. The mass-transport model includes processes related to vegetation snow-holding capacity, topographic modification of wind speeds, snow-cover shear strength, wind-induced surface-shear stress, snow transport resulting from saltation and suspension, snow accumulation and erosion, and sublimation of the blowing and drifting snow. The model simulates the coldseason evolution of snow-depth distribution when forced with inputs of vegetation type and topography, and atmospheric forcings of air temperature, humidity, wind speed and direction, and precipitation. Model outputs include the spatial and temporal evolution of snow depth resulting from variations in precipitation, saltation and suspension transport, and sublimation. Using 4 years of snow-depth distribution observations from the foothills north of the Brooks Range in Arctic Alaska, the model is found to simulate closely the observed snow-depth distribution patterns and the interannual variability.
\end{abstract}

\section{INTRODUGTION}

In the Arctic, on the prairies and in high-alpine regions, the combination of wind and snowfall play an important role in determining the winter snow distribution. Snow is scoured from ridges and windward slopes, and deposited in the lee of bluffs and other topographic obstructions; this wind-driven transport creates snow depths that can vary by a factor of ten or more over short distances. The interplay between wind and topography is the primary driver of this lateral snow movement, but vegetation and the moving snow itself also affect the transport through complex feedbacks and interactions. There has been considerable effort applied towards understanding and modeling snow-transport processes, with the goal of simulating and predicting snow distributions under a given set of topographic and weather conditions. These interactions are conceptually simple but, when trying to model all of the interactions occurring under a wide range of naturally occurring meteorological conditions and topographic configurations, model formulation and implementation can be challenging.

There are numerous reasons for needing to simulate or predict the wind redistribution of snow. In alpine regions, wind loading can lead to dangerous avalanche conditions and predictive snow-transport models can indicate when to close threatened highways, railroads and ski runs. In Arctic tundra regions, the uneven distribution of snow exerts strong control over plant-community distribution (Evans and others, 1989). This plant distribution, in conjunction with the snow-depth distribution, determines where caribou, muskoxen and other animals can find winter forage. Assessing sustainability of animal harvest for human consumption or predicting the impact of blizzards on the animals requires models capable of simulating the snow distribution. At the largest scale, seasonal snow cover, because of its low thermal conductivity, high albedo and high degree of spatial and temporal variability, plays an important role in governing the global radiation balance. In the Northern Hemisphere, the mean monthly land area covered by snow ranges from 7 to $40 \%$ during an annual cycle, making snow the Earth's most rapidly varying large-scale surface feature (Hall, 1988). In regimes where snow drifting creates non-uniform snow accumulations, melting in spring creates a patchy mosaic of vegetation and snow that is particularly complex to describe and model, and has a direct impact on energy exchanges between the land and atmosphere (Liston, 1995). This patchy snow distribution can play an important role in determining the timing and magnitude of snowmelt run-off. To capture these processes in climate and hydrologic models, accurate descriptions of snow distribution are necessary.

The snow-transport model described in this paper builds on many previous snow-transport studies. These studies show that snow saltation and suspension are the main mechanisms for moving snow (Mellor, 1965; Kobayashi, 1972; Radok, 1977; Male, 1980; Takeuchi, 1980; Kikuchi, 1981; Schmidt, 1982, 1986; Maeno and others, 1985; Pomeroy, 1988; Pomeroy and Gray, 1990), and the empirical and analytical relationships between wind speed and transport rates developed by these researchers are found in their snow-transport models and those developed by others (e.g. Tabler and others, 1990; Uematsu and others, 1991; Liston and others, 1993a; Bintanja, 1998a, b; Sundsbø, 1997; Purves and others, 1998). Other studies have shown that sublimation of wind-transported snow can be important, reducing the snow-cover water balance by a significant fraction under certain conditions (Goodison, 1981; Benson, 1982; Benson and Sturm, 1993; Pomeroy and others, 1993, 1997). The rate of sublimation, though complicated, has been 
found to be a function of wind speed, air temperature, humidity, particle size and solar radiation reaching the particle surface (Thorpe and Mason, 1966; Schmidt, 1972, 1982, 1991; Lee, 1975; Tabler, 1975a, 1987; Male, 1980; Pomeroy, 1988; Déry and Taylor, 1996). Studies have also shown that there are changes in aerodynamic roughness with increasing wind velocity, due to the drifting snow itself (Owen, 1964; Budd and others, 1966; Kobayashi, 1979; Schmidt, 1980, 1982; Kikuchi, 1981; Greeley and Iversen, 1985; Pomeroy, 1988; Déry and Taylor, 1996), and the resulting formulations are frequently used in snow-transport models.

The patterns of accumulation and erosion around variable topographic features have been described (Mellor, 1965; Tabler and Schmidt, 1986; Benson and Sturm, 1993), simulated in wind-tunnels or using small-scale models (Finney, 1939; Kind, 1976; Tabler and Jairell, 1980; Iversen, 1981), and modeled numerically. Two-dimensional, or cross-section, models have been developed (Berg and Caine, 1975; Tabler, 1975b; Uematsu and others, 1991; Liston and others, 1993a; Sundsbø, 1997) that can predict the evolution of snowdrifts and the distribution of snow-related features along the wind-flow direction; for example, both upwind and downwind of a snow fence or ridge. Many of these two-dimensional models rely heavily on the work of Pomeroy, who developed a comprehensive snow-transport modeling system (the Prairie Blowing Snow Model) to simulate blowing- and drifting-snow processes on the Canadian Prairies (Pomeroy, 1988, 1989; Pomeroy and Gray, 1990, 1995; Pomeroy and others, 1993).

The requirements of three-dimensional snow-transport models, ones capable of producing spatially distributed maps of snow depth, have only recently been addressed. In a simulation of the three-dimensional snow distribution within a $68 \mathrm{~km}^{2}$ Arctic Canada watershed, Pomeroy and others (1997) divided the domain into blowing-snow source and sink regions (or elements) based on topography and vegetation characteristics. Using a simplified version of the Prairie Blowing Snow Model, which can be driven with monthly mean climatological data, a mass-balance computation was performed over each landscape element, yielding an end-of-winter snow distribution and simulation of the associated snow-transport-related fluxes. In another study, Purves and others (1998) developed a simple, rule- and cellbased model of snow transport and distribution.

In this paper, we present a physically based numerical snow-transport model (SnowTran-3D) that can be used to simulate snow-depth evolution over topographically variable terrain. The model was developed for, and tested in, an Arctic-tundra landscape but is applicable to other treeless areas such as prairies and alpine regions. It builds on previous snow-transport studies and modeling efforts but also includes several improvements. First, it is not restricted to two dimensions (i.e. two-dimensional snow cross-sections or profiles) but produces spatially distributed maps of snow depth or snow water-equivalence. It introduces the equations required to compute the saltating and turbulent-suspended mass flux in non-equilibrium transport conditions, such as occur when flow is accelerating or decelerating near a topographic obstruction. In addition to being able to handle wind speeds which vary over the domain, the model simulates snow deposition and erosion under conditions of variable wind direction over the domain (i.e. the model will handle convergent and divergent wind fields). As part of the simulation procedure, the model keeps track of each component of the transport (saltation, suspension and sublimation) as a function of time and can be used to assess the relative importance of these processes in the development of the final snow distribution. The model, which requires timeindependent inputs of vegetation type and topography, and time-dependent inputs of air temperature, humidity, precipitation and wind speed, and direction, has been validated against 4 years of detailed snow-depth maps from a $2 \mathrm{~km}$ by $3 \mathrm{~km}$ domain in the foothills north of the Brooks Range in Arctic Alaska.

\section{MODEL DESCRIPTION}

The snow-transport model is fully three-dimensional, in that it is implemented in two horizontal dimensions $(x$ and $y$ ), and evolves the snow and snow water-equivalent depth (the $z$ dimension) over a topographically variable domain. To simulate the $x$ and $y$ snow-transport contributions, the model formulation makes use of an additional coordinate system, $x^{*}(\mathrm{~m})$, defined by the wind-flow direction (increasing downwind). The snow fluxes are computed along $x^{*}$ and then separated into their $x$ and $y$ components. The model considers only non-equilibrium transport from the perspective of spatially accelerating and decelerating flow; nonequilibrium transport resulting from temporal wind-speed accelerations and decelerations are not accounted for. The model is applicable to horizontal domains ranging from several tens of meters to a few hundred kilometers on a side. The topography within the domain can vary from flat, to gently rolling, to highly varying, such as regions where flow separation might occur over sharp ridges, gullies or valleys.

Figure 1 illustrates the key input parameters (solar radiation, precipitation, wind speed and direction, air temperature, humidity, topography and vegetation snow-holding capacity), the key processes (saltation, turbulent suspension and sublimation) and the key outputs (spatial distribution of snow erosion and deposition) from the model. The six primary components of the snow-transport model are: (1) the computation of the wind-flow forcing field; (2) the wind shear stress on the surface; (3) the transport of snow by saltation; (4) the transport of snow by turbulent-suspension; (5) the sublimation of saltating and suspended snow, and (6) the accumulation and erosion of snow at the snow surface, a lower boundary that is allowed to move with time.

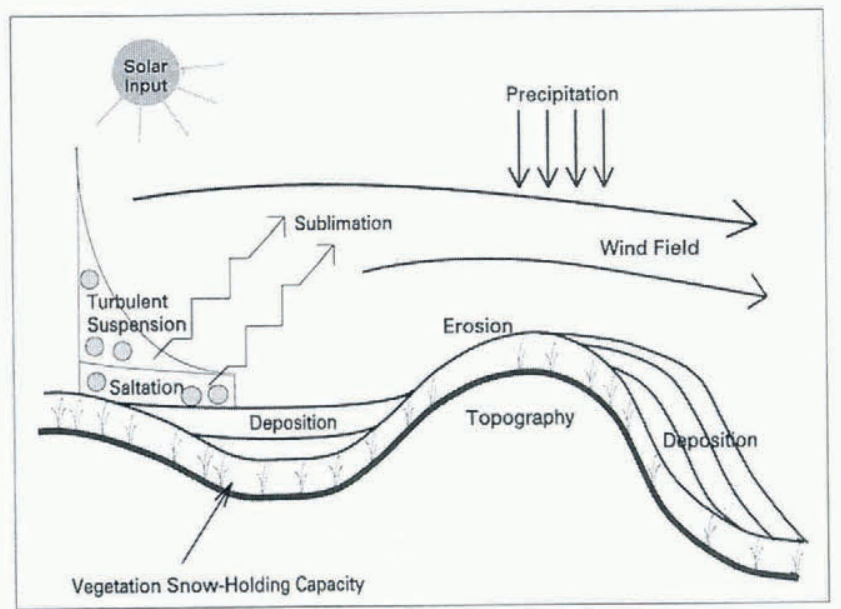

Fig. 1. Key features of the snow-transport model applied to topographically variable terrain. 


\section{a. Deposition and erosion}

The foundation of this snow-transport model is a massbalance equation which describes the temporal variation of snow depth at a point. Deposition and erosion, which lead to changes in snow depth at this point are the result of (1) changes in horizontal mass-transport rates of saltation, $Q_{\text {s }}$ $\left(\mathrm{kg} \mathrm{m}^{-1} \mathrm{~s}^{-1}\right),(2)$ changes in horizontal mass-transport rates of turbulent-suspended snow, $Q_{\mathrm{t}}\left(\mathrm{kg} \mathrm{m}^{-1} \mathrm{~s}^{-1}\right)$, (3) sublimation of transported snow particles, $Q_{\mathrm{v}}\left(\mathrm{kg} \mathrm{m}^{-2} \mathrm{~s}^{-1}\right)$ and (4) the water-equivalent precipitation rate, $P\left(\mathrm{~ms} \mathrm{~s}^{-1}\right)$. Combined, the time rate of change of snow depth, $\zeta(\mathrm{m})$, is

$$
\frac{\mathrm{d} \zeta}{\mathrm{d} t}=\frac{1}{\rho_{\mathrm{s}}}\left[\rho_{\mathrm{w}} P-\left(\frac{\mathrm{d} Q_{\mathrm{s}}}{\mathrm{d} x}+\frac{\mathrm{d} Q_{\mathrm{t}}}{\mathrm{d} x}+\frac{\mathrm{d} Q_{\mathrm{s}}}{\mathrm{d} y}+\frac{\mathrm{d} Q_{\mathrm{t}}}{\mathrm{d} y}\right)+Q_{\mathrm{v}}\right]
$$

where $t(\mathrm{~s})$ is time; $x(\mathrm{~m})$ and $y(\mathrm{~m})$ are the horizontal coordinates in the west-east and south-north directions, respectively; and $\rho_{\mathrm{s}}$ and $\rho_{\mathrm{w}}\left(\mathrm{kg} \mathrm{m}^{-3}\right)$ are the snow and water density, respectively. Figure 2 provides a schematic of this mass-balance accounting. Equation (1) is solved for each individual grid cell within a domain and is coupled to the neighboring cells through the spatial derivatives $(\mathrm{d} / \mathrm{d} x, \mathrm{~d} / \mathrm{d} y)$.

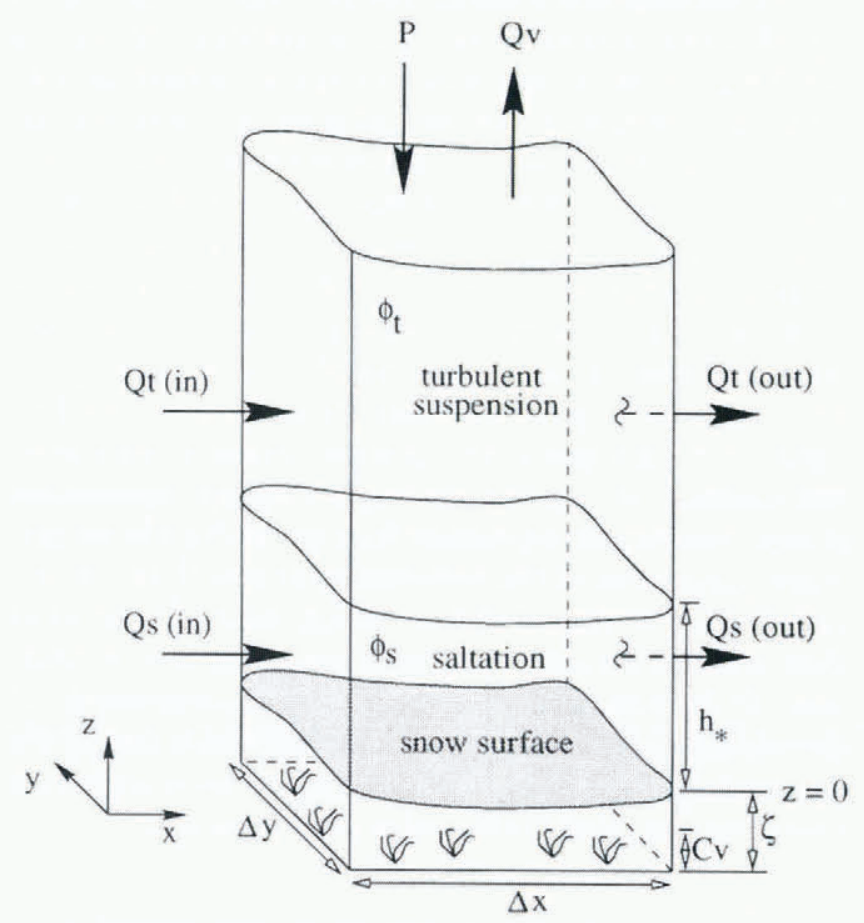

Fig. 2. Schematic of the snow-transport model mass-balance computation.

\section{b. Surface shear stress}

The shear stress that wind exerts on the surface largely determines whether the wind speed is sufficient to transport snow. This shear stress is formulated in terms of the windshear (or friction) velocity, $u_{*}\left(\mathrm{~m} \mathrm{~s}^{-1}\right)$, which is given by

$$
u_{*}=u_{\mathrm{r}} \frac{\kappa}{\ln \left(z_{\mathrm{r}} / z_{0}\right)}
$$

where $u_{\mathrm{r}}\left(\mathrm{m} \mathrm{s}^{-1}\right)$ is the wind speed at reference height $z_{\mathrm{r}}(\mathrm{m})$, $z_{0}(\mathrm{~m})$ is the surface roughness length, and $\kappa$ is von Kármán's constant. If the wind-shear velocity exceeds the threshold shear velocity, $u_{* \mathrm{t}}\left(\mathrm{m} \mathrm{s}^{-1}\right)$, of the snow cover and, if snow is available, saltation will begin.

The availability of snow for transport is determined by defining a snow-holding capacity, $C_{\mathrm{v}}(\mathrm{m})$, for each vegetation type or land-surface classification within the domain. This capacity is a function of vegetation height and density, and/or microtopographic relief. Precipitation is converted to snowfall using the snow density and accumulates until the snow depth exceeds the vegetation snow-holding capacity. Once exceeded, any additional snow is available for wind transport.

To account for regions within the domain where the snow depth does not completely cover the vegetation, $z_{0}$ is determined by linearly weighting the vegetation roughness length, $z_{0_{-} \text {veg, }}$ and the roughness length defined for snow, $z_{0 \_ \text {snow }}$, according to the depth-fraction of vegetation covered by snow, $F_{\mathrm{s}}$

$$
F_{\mathrm{s}}=\frac{\zeta}{C_{\mathrm{v}}}
$$

where, in this case, the snow depth, $\zeta$, is less than or equal to the vegetation snow-holding capacity, $C_{\mathrm{v}}$. Thus, the roughness length, $z_{0}$, is given by

$$
z_{0}=F_{\mathrm{s}} z_{0 \_ \text {snow }}+\left(1-F_{\mathrm{s}}\right) z_{0 \_ \text {veg }} .
$$

This allows the computation of a spatially continuous wind field, including regions in the domain where the vegetation snow-holding capacity has not been reached.

Given sufficient winds and snow depths above the vegetation snow-holding capacity, snow will begin to saltate. When it does, the wind-shear velocity, $u_{*}\left(\mathrm{~m} \mathrm{~s}^{-1}\right)$ and the roughness length, $z_{0}$, are coupled (Owen, 1964; Tabler, 1980) and described by Equation (2), and

$$
z_{0}=0.12 \frac{u_{*}^{2}}{2 g}
$$

where $g\left(\mathrm{~m} \mathrm{~s}^{-2}\right)$ is the gravitational acceleration. To determine whether snow is saltating, we first assume that saltation is present and then solve Equations (2) and (5) for $u_{*}$ and $z_{0}$ using Newton-Raphson iteration. If the resulting $u_{*}$ exceeds a threshold shear velocity, $u_{* t}$, then saltation is present. If not, $z_{0}=z_{0 \_ \text {snow }}$ is defined for the stationary snow cover and $u_{*}$ is computed using Equation (2) alone. In contrast to Pomeroy (1988), who was interested in agricultural fields containing large fractions of wheat stubble, we have assumed, largely due to lack of data, that stalks of vegetation protruding above the snow-holding-capacity height have a negligible influence on the roughness-length computation.

\section{c. Saltation}

Under equilibrium conditions, Pomeroy and Gray (1990) found that the saltation-transport rate, $Q_{\text {s_max }}\left(\mathrm{kg} \mathrm{m}^{-1} \mathrm{~s}^{-1}\right)$, can be described by

$$
Q_{\mathrm{s} \text { max }}=\frac{0.68}{u_{*}}\left(\frac{\rho_{\mathrm{a}}}{g}\right) u_{* \mathrm{t}}\left(u_{*}^{2}-u_{* \mathrm{t}}^{2}\right)
$$

where $\rho_{\mathrm{a}}\left(\mathrm{kg} \mathrm{m}^{-3}\right)$ is the air density. In general, $u_{*}$ will vary in space and time, so $Q_{\text {s_max }}$ will also vary. In addition, $Q_{\text {s_max }}$ will be achieved only if there is sufficient fetch distance to entrain the full amount of snow that the wind speed, via $u_{*}$, is capable of carrying.

For the non-equilibrium (and equilibrium) conditions of 
interest in the current study, the saltation-transport rate, $Q_{\mathrm{s}}$ $\left(\mathrm{kg} \mathrm{m}^{-1} \mathrm{~s}^{1}\right)$, is assumed to follow

$$
\frac{\mathrm{d} Q_{\mathrm{s}}\left(x^{*}\right)}{\mathrm{d} x^{*}}=\frac{\mu}{f}\left(Q_{\mathrm{s} \_\max }\left(x^{*}\right)-Q_{\mathrm{s}}\left(x^{*}\right)\right) \quad \text { for } \frac{\partial u_{*}}{\partial x^{*}} \geq 0
$$

and

$$
Q_{\mathrm{s}}\left(x^{*}\right)=\min \left\{\begin{array}{l}
Q_{\mathrm{s}}\left(x^{*}-\Delta x^{*}\right) \\
Q_{\mathrm{s} \_ \text {max }}\left(x^{*}\right)
\end{array} \quad \text { for } \frac{\partial u_{*}}{\partial x^{*}}<0\right.
$$

where $x^{*}(\mathrm{~m})$ is the horizontal coordinate in a reference frame defined by the wind-flow direction (increasing downwind); $\Delta x^{*}(\mathrm{~m})$ is horizontal grid resolution; $\mu$ is a nondimensional scaling constant, and $f(\mathrm{~m})$ is the equilibrium-fetch distance, assumed to be somewhere between the $300 \mathrm{~m}$ suggested by Takeuchi (1980) and the $500 \mathrm{~m}$ adopted by Pomeroy and others (1993).

For the case of decreasing wind-shear velocity with distance downwind, Equation (8) sets the saltation flux to be the minimum of either (a) that which can be supported by the wind-shear velocity, or (b) the saltation flux available from the upwind grid cell. For the case of constant or increasing wind-shear velocity with distance, Equation (7), discretized as

$$
\begin{aligned}
Q_{\mathrm{s}}\left(x^{*}\right) & =Q_{\mathrm{s}}\left(x^{*}-\Delta x^{*}\right)+\frac{\mu}{f} \Delta x^{*} \\
& \left(Q_{\mathrm{s} \_ \text {max }}\left(x^{*}\right)-Q_{\mathrm{s}}\left(x^{*}-\Delta x^{*}\right)\right) \text { for } \frac{\partial u_{*}}{\partial x^{*}} \geq 0
\end{aligned}
$$

considers the upwind saltation flux (at $\left.x^{*}-\Delta x^{*}\right)$ and adds a bit more to it, to get the flux at $x^{*}$. The amount added decreases as $Q_{\text {s_max }_{\text {max }}}\left(x^{*}\right)$ is approached, until the fetch distance, $f$, has been reached or exceeded, at which point the saltation flux becomes constant at $Q_{\mathrm{s}}\left(x^{*}\right) \approx Q_{\mathrm{s} \_ \text {max }}$; thus, Equation (6) is recovered as equilibrium is reached. To solve Equations (8) and (9) (and Equation (1), as discussed later), the saltation flux at upwind boundaries of the domain must be provided. At such a boundary, we assume that sufficient fetch and snow supply is available to reach equilibrium, and the inflow boundary condition is given by Equation (6). Because non-equilibrium transport resulting from temporal wind-speed accelerations and decelerations are not considered, initial conditions in the form of transport fluxes are not required and the transport fluxes at one time-step do not influence the transport at the next time-step.

As a further illustration of the non-equilibrium saltation-transport model behavior, consider an example where the saltation flux at the upwind boundary is zero, $Q_{\mathrm{s}}\left(x^{*}=0\right)=0$; such a condition might occur at the downwind edge of a drift trap. With this boundary condition and a constant wind-shear velocity $\left(Q_{\mathrm{s}}\left(x^{*}\right)=Q_{\text {s_max }}\right.$ $=$ constant), Equation (7) has the solution

$$
Q_{\mathrm{s}}\left(x^{*}\right)=Q_{\mathrm{s} \_ \text {max }}\left[1-\exp \left(-\mu \frac{x^{*}}{f}\right)\right]
$$

which is shown in Figure 3, where $\mu=3.0$ has been chosen such that $Q_{\mathrm{s}}\left(x^{*}=f=500 \mathrm{~m}\right)$ equals $95 \%$ of $Q_{\mathrm{s}_{\max }}$.

\section{d. Suspension}

Saltation must be present in order to have turbulent-suspended snow particles, and the saltation-transport rate provides the lower boundary condition for determining whether, and the degree to which, suspended transport

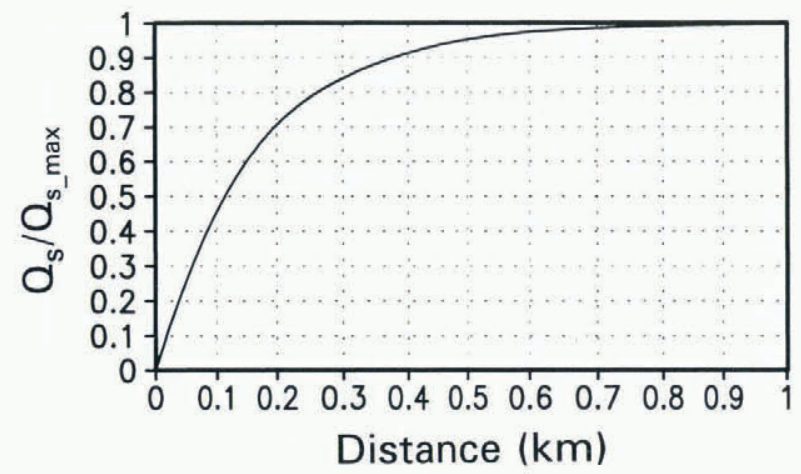

Fig. 3. Heterogeneous progression of saltation transport given by Equations (7) (and (9)) for conditions of $\mu=3.0$, constant surface-shear velocity and an upwind boundary condition flux $\left(\right.$ at $\left.x^{*}=0\right)$ equal to zero. For this case, 95\% of equilibrium transport occurs at a fetch distance of $0.5 \mathrm{~km}$.

occurs. The transport rate of turbulent-suspended snow, $Q_{\mathrm{t}}$ $\left(\mathrm{kg} \mathrm{m}^{-1} \mathrm{~s}^{-1}\right)$, is given by

$$
Q_{\mathrm{t}}\left(x^{*}\right)=\int_{h_{*}}^{z_{\mathrm{t}}} \phi_{\mathrm{t}}\left(x^{*}, z\right) u\left(x^{*}, z\right) \mathrm{d} z
$$

where $z$ is the height coordinate, $\phi_{\mathrm{t}}\left(\mathrm{kg} \mathrm{m}^{-3}\right)$ is the mass concentration of the particulate cloud, $u\left(\mathrm{~m} \mathrm{~s}^{-1}\right)$ is the wind velocity given by Equations (2) and (5), and the integration limits are the top of the saltation layer, $h_{*}(\mathrm{~m})$, and the top of the turbulent-suspension layer, $z_{\mathrm{t}}(\mathrm{m})$, where the concentration is zero.

The concentration of blowing snow within the turbulent-suspension layer, $\phi_{\mathrm{t}}$, is defined according to Kind (1992) as

$$
\phi_{\mathrm{t}}\left(x^{*}, z\right)=\phi_{\mathrm{r}}\left[\left(\frac{\phi^{*}}{\phi_{\mathrm{r}}} \frac{u_{*}}{s}+1\right)\left(\frac{z}{z_{\mathrm{tr}}}\right)^{-s / \kappa u^{*}}-\frac{\phi^{*}}{\phi_{\mathrm{r}}} \frac{u_{*}}{s}\right]
$$

where $\phi_{\mathrm{r}}$ is the mass concentration at some reference level, $z_{\mathrm{tr}}(\mathrm{m})$ near the surface; $s\left(\mathrm{~ms}^{-1}\right)$ is the particle-settling velocity, assumed to be $0.3 \mathrm{~m} \mathrm{~s}^{-1}$ (Schmidt, 1982); and $\phi^{*}$ is a concentration scaling parameter. This formulation assumes that the concentration is in local equilibrium with the reference-level concentration and does not take into account any advective or non-steady affects. The ratio of the scaling parameter to the reference mass-concentration is approximated by

$$
\frac{\phi^{*}}{\phi_{\mathrm{r}}}=\beta \frac{u_{*}}{u_{\mathrm{r}}}
$$

where $\beta$ is a coefficient assumed to be 0.5 (Kind, 1992).

To solve Equation (12), the concentration reference level, $z_{\mathrm{tr}}(\mathrm{m})$, is defined to be the top of the saltation layer, at height $h_{*}(\mathrm{~m})$. This approach ensures continuity at the saltation/turbulent-suspension interface, and provides a method to define the lower boundary condition of the turbulent-flow regime based on our understanding of the conditions within the saltation layer. The saltation-layer height is estimated following Greeley and Iversen (1985),

$$
h_{*}=1.6 \frac{u_{*}^{2}}{2 g} .
$$

Pomeroy and Gray (1990) suggested that the horizontal particle velocity within the saltation layer, $u_{\mathrm{p}}\left(\mathrm{m} \mathrm{s}^{-1}\right)$, is constant with height and approximated by

$$
u_{\mathrm{p}}=2.8 u_{* \mathrm{t}} \text {. }
$$

Under the further assumption that the saltation-layer mass 


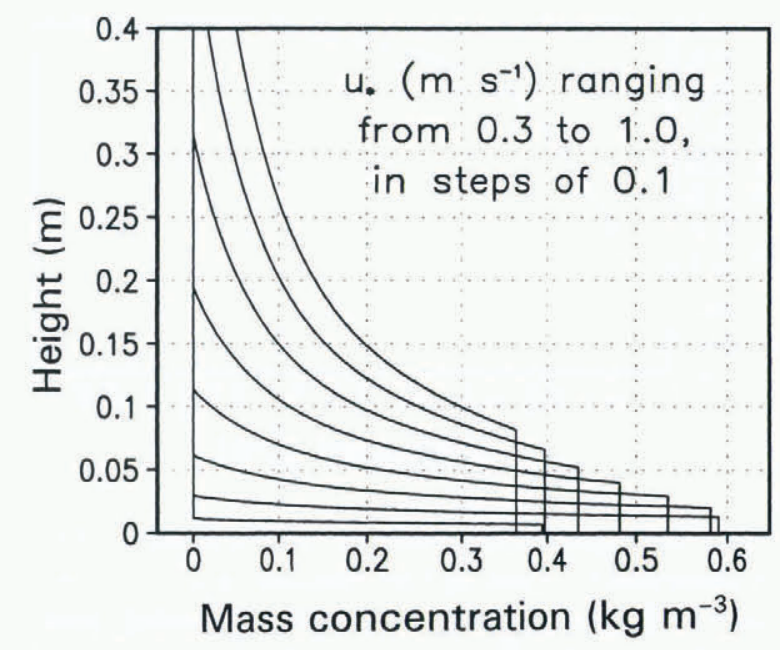

Fig. 4. Vertical profiles of mass concentration for saltation and turbulent-suspended transport, for the case of $u_{* \mathrm{t}}=$ $0.25 \mathrm{~m} \mathrm{~s}^{-1}, Q_{\mathrm{s}}=Q_{\mathrm{s} \text { max }}$ from Equation (6), and a variable wind-shear velocity. The increase in saltation-layer height with increasing wind-shear velocity is evident in the profiles.

flux is also independent of height, the saltation-layer reference-level mass concentration, $\phi_{\mathrm{r}}\left(\mathrm{kg} \mathrm{m}^{-3}\right)$, is given by

$$
\phi_{\mathrm{r}}=\frac{Q_{\mathrm{s}}}{h_{*} u_{\mathrm{p}}}
$$

where $Q_{\mathrm{s}}$ is given by Equations (8) and (9). Figure 4 illustrates the vertical profile of mass concentration for both saltation and suspended transport, for the case of $u_{* \mathrm{t}}=0.25 \mathrm{~m} \mathrm{~s}^{-1}, Q_{\mathrm{s}}=Q_{\mathrm{s} \_\max }$ from Equation (6), and $u_{*}$ ranging from $0.3 \mathrm{~m} \mathrm{~s}^{-1}$ to $1.0 \mathrm{~m} \mathrm{~s}^{-1}$ in steps of 0.1 . While the height-independent saltation-layer mass-concentration is an oversimplification (Kobayashi, 1972; Takeuchi, 1980; McKenna-Neuman and Nickling, 1994), this approximation is used until a more realistic description is available.

Figure 5 shows the variation of saltation and turbulentsuspension transport with wind-shear velocity, for the case of $u_{* \mathrm{t}}=0.25 \mathrm{~m} \mathrm{~s}^{-1}$ and $Q_{\mathrm{s}}=Q_{\text {s_max }}$ from Equation (6). In this example, suspended transport is zero between windshear velocities of 0.25 and 0.31 , and saltation is the only transport mechanism. At a wind-shear velocity of 0.44 , saltation and suspension transport become equal, and above that value suspension rapidly begins to dominate transport.

\section{e. Sublimation}

During transport by saltation and turbulent suspension, snow particles lose mass to the atmosphere through sublimation. In addition, the snow-cover surface can exchange moist-

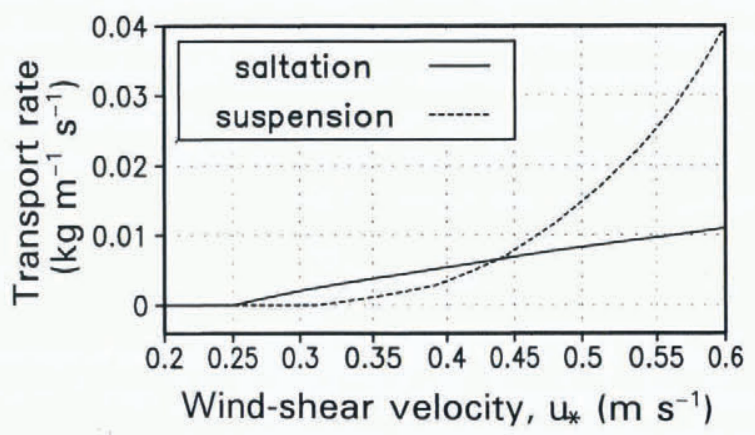

Fig. 5. Variation of saltation and turbulent-suspension transport with wind-shear velocity for the case of $u_{* \mathrm{t}}=0.25 \mathrm{~m}$, and $Q_{\mathrm{s}}=Q_{\mathrm{s} \_\max }$ from Equation (6). ure with the atmosphere by sublimation under non-transport conditions, but at a much lower rate than during transport. In this study, we only consider the snow mass lost during snow transport by the wind. The sublimation rate of transported snow, per unit area of snow cover, $Q_{\mathrm{v}}\left(\mathrm{kg} \mathrm{m}^{-2} \mathrm{~s}^{-1}\right)$, is given by

$$
Q_{\mathrm{v}}\left(x^{*}\right)=\int_{0}^{z_{\mathrm{t}}} \Psi\left(x^{*}, z\right) \phi\left(x^{*}, z\right) \mathrm{d} z
$$

where $\Psi\left(\mathrm{s}^{-1}\right)$ is the sublimation-loss rate coefficient, $\phi$ $\left(\mathrm{kg} \mathrm{m}^{-3}\right)$ is the vertical mass-concentration distribution, and the integration limits are from the snow surface through the saltating and turbulent-transport regimes. If the saltation-layer contribution $\left(z=0\right.$ to $\left.z=h_{*}\right)$, where we have assumed constant flow properties with height, is separated from the turbulent-suspension layer contribution, Equation (17) becomes

$$
Q_{\mathrm{v}}\left(x^{*}\right)=\Psi_{\mathrm{s}} \phi_{\mathrm{s}} h_{*}+\int_{h_{*}}^{z_{\mathrm{t}}} \Psi_{\mathrm{t}}\left(x^{*}, z\right) \phi_{\mathrm{t}}\left(x^{*}, z\right) \mathrm{d} z
$$

where here the subscripts $\mathrm{s}$ and $\mathrm{t}$ refer to the saltation and turbulent-suspension layers, respectively, and the saltationlayer mass concentration, $\phi_{\mathrm{s}}\left(\mathrm{kg} \mathrm{m}^{-3}\right)$, is given by Equation (16).

Our formulation for the sublimation rate of wind-transported snow, $Q_{\mathrm{v}}$, follows that of Schmidt (1972, 1991), Pomeroy and others (1993) and Pomeroy and Gray (1995). The sublimation-loss-rate coefficient, $\Psi$, describing the rate of particle mass-loss as a function of height within the blowing and drifting-snow profile, is a function of (1) temperaturedependent humidity gradients between the snow particle and the atmosphere, (2) conductive and advective energyand moisture-transfer mechanisms, (3) particle size, and (4) solar radiation intercepted by the particle. In addition, we assume that (a) the mean particle size decays exponentially with height, (b) the relative humidity follows a logarithmic distribution, decreasing with height, (c) the air temperature in the snow-transport layer is well mixed and constant with height, (d) the variables defined within the saltation layer are constant with height, and those in the turbulent-suspension layer vary with height, and (e) the solar radiation absorbed by snow particles is a function of the solar-elevation angle (latitude, time-of-day, day-of-year) and fractional cloud cover, $\sigma_{\mathrm{c}}$. The details of this formulation are given in the Appendix.

\section{f. Wind field}

To drive the snow-transport model, a reference-level windflow field, $u_{\mathrm{r}}$, over the domain is required at each model time-step. This wind field can be generated by several methods, including (in decreasing order of complexity or difficulty), (1) applying a physically based, full atmospheric model (e.g. the Regional Atmospheric Modeling System (RAMS); Pielke and others, 1992), or a boundary-layer circulation model (e.g. Liston and others, 1993b; Liston, 1995), both of which satisfy all relevant momentum and continuity equations, (2) applying an atmospheric model in which only mass continuity is satisfied (e.g. Sherman, 1978; Ross and others, 1988), (3) interpolation using extensive (windwardand lee-slope) wind speed and direction observations, or (4) interpolation using wind-speed and direction observations in conjunction with empirical wind-topography relationships (e.g. Ryan, 1977).

To minimize computational expense, the current study 
uses method (4). Observed wind speeds in the domain are interpolated to the model grid and then the wind-speed field, $u_{\mathrm{r}}$, is modified to account for topographic variations by multiplying by an empirically based weighting factor, $W$,

$$
W=1.0+\gamma_{\mathrm{s}} \Omega_{\mathrm{s}}+\gamma_{\mathrm{c}} \Omega_{\mathrm{c}}
$$

where $\Omega_{\mathrm{s}}$ and $\Omega_{\mathrm{c}}$ are the topographic slope and curvature, respectively, in the direction of the wind, and $\gamma_{\mathrm{s}}$ and $\gamma_{\mathrm{c}}$ are positive constants which weight the relative influence of $\Omega_{\mathrm{s}}$ and $\Omega_{\mathrm{c}}$ on modifying the wind speed. The slope and curvature are computed such that lee and concave slopes produce $\Omega_{\mathrm{s}}$ and $\Omega_{\mathrm{c}}$ less than zero, and that windward and convex slopes produce $\Omega_{\mathrm{s}}$ and $\Omega_{\mathrm{c}}$ greater than zero. Thus, lee and concave slopes produce reduced wind speeds, and windward and convex slopes produce increased wind speeds. Values of $\gamma_{\mathrm{s}}=11$ and $\gamma_{\mathrm{c}}=360$ have been found to produce wind-speed variations, in response to topography, which are consistent with observations of wind-microtopographic relationships (Kreutz and others, 1955; Nägeli, 1971; Yoshino, 1975), and have been used in this study. In this application, because of the relatively gentle nature of the local topography, the wind direction is assumed to be unaffected by topography; a point verified by measurements of surface-drift features in our Arctic test domain (König, 1997). The topographically modified wind field is used to compute the $u_{*}$ distribution by applying Equations (2) and (5), and $Q_{\text {s_max }}$ is computed for each gridcell using Equation (6).

The horizontal coordinate $x^{*}$, used in Equations (2) through (19), is aligned with the wind direction. To simulate the snow-depth evolution on a rectangular grid, the snow fluxes are computed along $x^{*}$ and then separated into their $x$ and $y$ components. The wind-field, $u_{\mathrm{r}}$ (Fig. 6a), is broken into its vector components, $u$ (east-west) and $v$ (north-south) (Fig. 6b and c). These are used to identify sub-domains in which the $u$ and $v$ components come from the same direction: east or west sub-domains for $u$, and north or south subdomains for $v$ (Fig. $6 \mathrm{~b}$ and $\mathrm{c}$ ). The magnitudes of the windvelocity components are used to partition $Q_{\text {s_max }}$ into an $x$ and $y$ component such that the vector sum of the $u$ and $v$ contributions equal $Q_{\text {s_max }}$

$$
Q_{\text {s_max }}(x)=Q_{\text {s_max }} \frac{|u|}{\sqrt{u^{2}+v^{2}}}
$$

and

$$
Q_{\mathrm{s} \_ \text {max }}(y)=Q_{\mathrm{s} \_ \text {max }} \frac{|v|}{\sqrt{u^{2}+v^{2}}} .
$$

Equations (8) and (9) are then applied in the wind-flow direction for each sub-domain, where $Q_{\text {s_max }}$ in Equations (8) and (9) is replaced by $Q_{\mathrm{s} \_ \text {max }}(x)$ or $Q_{\mathrm{s} \_ \text {max }}(y)$ (Equations (20) or (21)), for the $x$ and $y$ directions, respectively. These components are then used in the solution of Equation (1).

\section{GOMPUTATIONAL RESULTS}

The snow-transport model was applied to a $6 \mathrm{~km}^{2}$ area that includes Imnavait Creek, in Arctic Alaska (Fig. 7). Imnavait Creek is a $2.2 \mathrm{~km}^{2}$ basin located between the headwaters of the Kuparuk and Toolik Rivers at $68^{\circ} 37^{\prime} \mathrm{N}, 149^{\circ} 17^{\prime} \mathrm{W}$, and an elevation of approximately $900 \mathrm{~m}$. The topography,
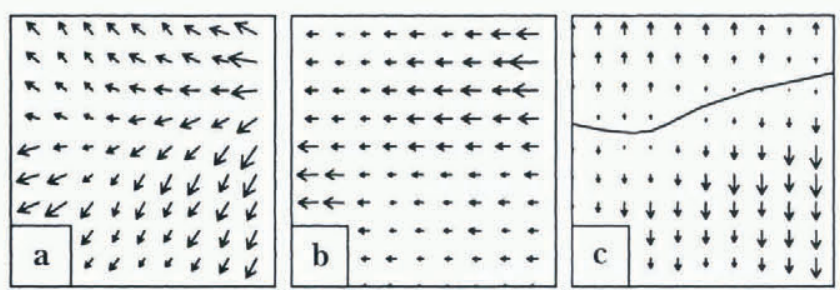

Fig. 6. (a) Example two-dimensional ( $x$ and $y$ ) gridded convergent/divergent wind-flow field. (b) $u$ component of example flow field, with entire domain having flow from the east. (c) $v$ component of example flow field, with two subdomains, one having flow from the south (top sub-domain) and one having flow from the north (bottom sub-domain).

physiography and vegetation of the watershed are representative of the area north of the Brooks Range and south of the Arctic Coastal Plain (Wahrhaftig, 1965). The vegetation covering the site is composed of low-growing sedges and grasses roughly $15 \mathrm{~cm}$ in height, with occasional groupings of taller willows, approximately $40 \mathrm{~cm}$ high, located in hillside water tracts and valley bottoms (Fig. 7). Tussock-tundra covers much of the area, with swampy features in the valley bottoms, and dry rocky outcrops on the exposed ridges. The topography is characterized by gently rolling ridges and valleys having wavelengths of $1-2 \mathrm{~km}$ and amplitudes of 25-75 m (Fig. 7). These ridges are aligned nearly northsouth. Also, within the domain are several more-pronounced topographic features having much shorter and steeper slopes (up to $30^{\circ}$ slopes over distances of a few tens of meters), such as the "S2-Drift" (Fig. 7).

Model simulations were run from 1 September through 30 April, for the winters 1986-87, 1987-88, 1988-89 and

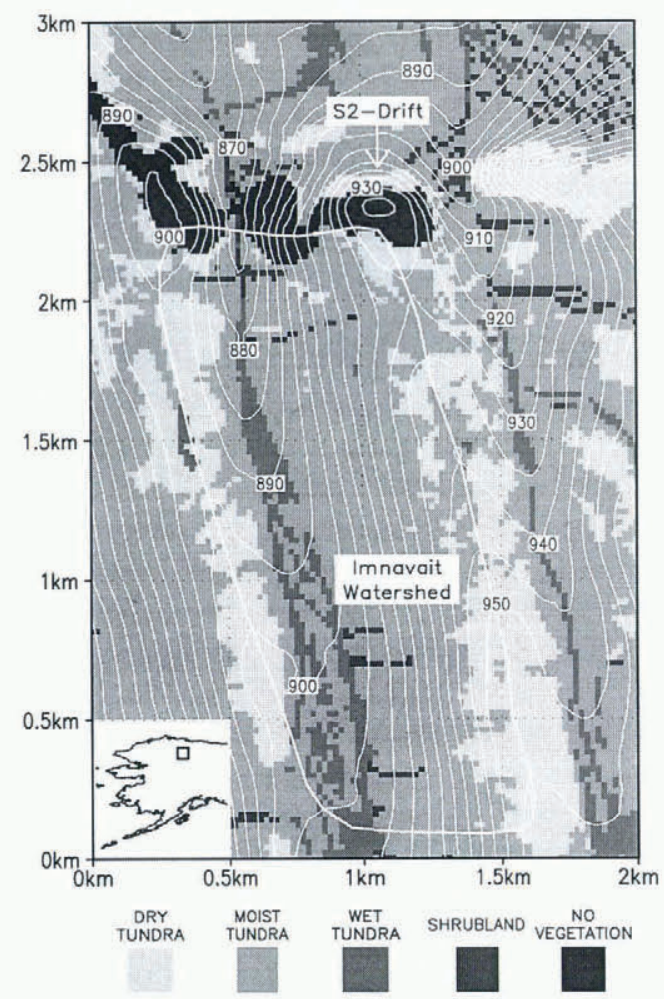

Fig. 7. Vegetation and topography for the 2 by $3 \mathrm{~km}$ Imnavait Creek simulation domain. Topographic contour interval is $5 \mathrm{~m}$. Also shown is the location of the Imnavait watershed boundary. (Data courtesy of $\mathcal{N}$. Auerbach and S. Walker, Institute of Arctic and Alpine Research, Boulder, Colorado.) 
1989-90. In the discussions which follow, these periods are referred to as 1987, 1988, 1989 and 1990, respectively. The simulations were run with a $20 \mathrm{~m}$ by $20 \mathrm{~m}$ grid spacing and a 1 day time-step. Table 1 summarizes the user-defined constants used in the simulations.

\section{a. Atmospheric forcing}

Climate data from two meteorological towers in Imnavait Creek were obtained from the Water Research Center, University of Alaska, Fairbanks, and used to provide atmospheric forcing for the model simulations. A continuous, daily meteorological record of air temperature, humidity,

\section{Table 1. User-defined constants used in model simulations}

\begin{tabular}{|c|c|c|}
\hline \multirow[t]{6}{*}{$C_{\mathrm{v}}$} & & $\begin{array}{l}\text { Vegetation snow-holding capacity }(\mathrm{m}) \\
\text { (see Fig. } 7 \text { for vegetation types) }\end{array}$ \\
\hline & 0.10 & Dry tundra \\
\hline & 0.20 & Moist tundra \\
\hline & 0.30 & Wet tundra \\
\hline & 0.40 & Shrubland \\
\hline & 0.05 & No vegetation \\
\hline \multirow[t]{6}{*}{$z_{0 \text {-veg }}$} & & $\begin{array}{l}\text { Vegetation roughness length }(\mathrm{m}) \\
\text { (see Fig. } 7 \text { for vegetation types) }\end{array}$ \\
\hline & 0.050 & Dry tundra \\
\hline & 0.100 & Moist tundra \\
\hline & 0.150 & Wet tundra \\
\hline & 0.200 & Shrubland \\
\hline & 0.025 & No vegetation \\
\hline$f$ & 500.0 & $\begin{array}{l}\text { Equilibrium fetch distance }(\mathrm{m}) \\
\text { (Pomeroy and others, 1993) }\end{array}$ \\
\hline$u_{* t}$ & 0.25 & Threshold wind-shear velocity $\left(\mathrm{m} \mathrm{s}^{-1}\right)$ (Schmidt, 1986) \\
\hline$z_{0 \text { _snow }}$ & 0.005 & Snow-roughness length $(\mathrm{m})$ \\
\hline$\Upsilon_{\mathrm{c}}$ & 360 & Topographic curvature weighting factor \\
\hline$\Upsilon_{s}$ & II & Topographic slope weighting factor \\
\hline$\mu$ & 3.0 & Scaling constant for non-equilibrium saltation transport \\
\hline$\rho_{\mathrm{s}}$ & 280.0 & Snow density $\left(\mathrm{kg} \mathrm{m}^{-3}\right)$ (Benson and Sturm, 1993) \\
\hline$\sigma_{\mathrm{c}}$ & 0.5 & Cloud-cover fraction (Hare and Hay, 1974) \\
\hline
\end{tabular}

and wind speed and direction, was produced by merging data from one tower to another if one tower failed, and by linearly interpolating between data values on the few occurrences when both meteorological towers failed (Fig. $8 \mathrm{a}-\mathrm{d}$; Table 2).

Reliable (or even unreliable) winter precipitation measurements for the Arctic in general, and the test domain in particular, do not exist (Benson, 1982). To generate a daily precipitation dataset for the model simulations, it was necessary to adopt the following procedure: snow precipitation was assumed to fall when the air temperature was below freezing and the relative humidity was greater than $80 \%$. For each day meeting these criteria, the number of humidity percentage points above $80 \%$ was divided by the total number of percentage points above $80 \%$ for the entire winter. This produced a snow-precipitation factor equal to the fraction of total winter snowfall that occurred on each day. The daily factor, when multiplied by an estimate of the total endof-winter precipitation, produced the precipitation amount for the day. Using this precipitation index factor reduced the problem of defining daily winter precipitation to one of only needing to know the total winter precipitation. Unfortunately, that too was unknown, but we did know, from our field observations, the end-of-winter snow water-equivalent depth. So, the model was run in an iterative "data assimilation" mode, where the total winter precipitation was adjusted until the model-produced end-of-winter snow water- equivalent depths closely matched those measured in Imnavait Creek (Table 3) (Kane and others, 1991; Hinzman and others, 1996; Benson, unpublished data). In the simulations, precipitation was assumed to be spatially uniform over the domain. The total winter precipitation values necessary to produce the spatially averaged snow water-equivalent depths given in Table 3 are included in Table 2. In addition, the daily snow-precipitation forcing used in the model simulations is included in Figure $8 \mathrm{a}-\mathrm{d}$.

We found the model to be relatively insensitive to the value chosen for the threshold relative humidity $(80 \%)$, which effectively determined when it snowed. In the Arctic, low winter temperatures mean that the shear strength of new snow is relatively low long after it snows. Thus, the timing between precipitation and wind events is not as critical as in warmer climates, where snow that accumulates a few days (or even hours) before the wind blows, may have strengthened to the point that it is unavailable for transport at naturally occurring wind speeds. In applications where the snow shear strength increases significantly following precipitation events, the method we use to determine precipitation timing and quantity would be inappropriate.

\section{b. Observed snow distributions}

Observed end-of-winter snow distribution maps for 1987, 1988, 1989 and 1990 for the domain shown in Figure 7 are presented in Figure 9. These maps, part of a sequence that began in 1985, have been prepared from a combination of ground-based depth and density measurements, and aerial photographs (Liston, 1986; Hinzman and others, 1996; König, 1997; Benson, unpublished data). As an example of how these maps were developed, in 1985 three sets of oblique aerial photographs were taken: the first set was taken prior to any melting, when the snow depth was at a maximum; the second set was taken 6 days into the melt when $90 \%$ of the site was snow-covered; and the third set was taken 13 days into the melt when $20 \%$ of the site was snow-covered. For each of the three sets of aerial photographs, maps were drawn outlining the snow-vegetation boundaries. These three maps were merged into a common snow-pattern map, to which the snow water-equivalent depth observations were added. Analysis of the ground-based observations and the snow-pattern map showed that the map could be used to extrapolate snow-depth data into regions without direct measurements.

The accuracy of the observed snow-distribution maps (Fig. 9) can be variable, depending on the number of ground-based measurements and the number and quality of aerial photographs. In general, boundaries on the maps are somewhat simplified and idealized, though actual snow water-equivalent depth values within mapped areas are assumed fairly accurate. Small-scale features, like hollows and depressions that might hold deeper snow, tended to fall below the spacing of depth and snow water-equivalent measurements and are not depicted in the maps. For simplicity in discussion and comparing model results to measured values, we refer to these maps as the "measured or observed snow distribution" but, in reality, the true distribution of snow is not known. In some cases, we suspect that the measured snow-distribution maps contain errors in boundary locations and depths that are greater than the errors within the modeled snow distributions. 


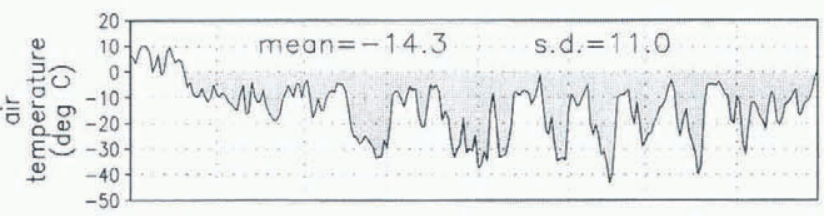

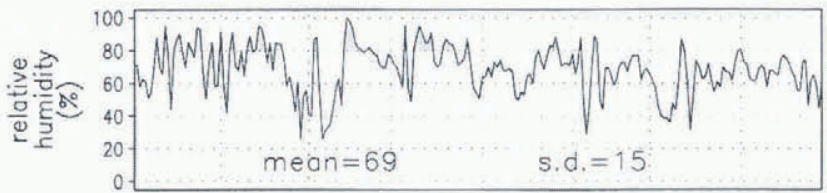
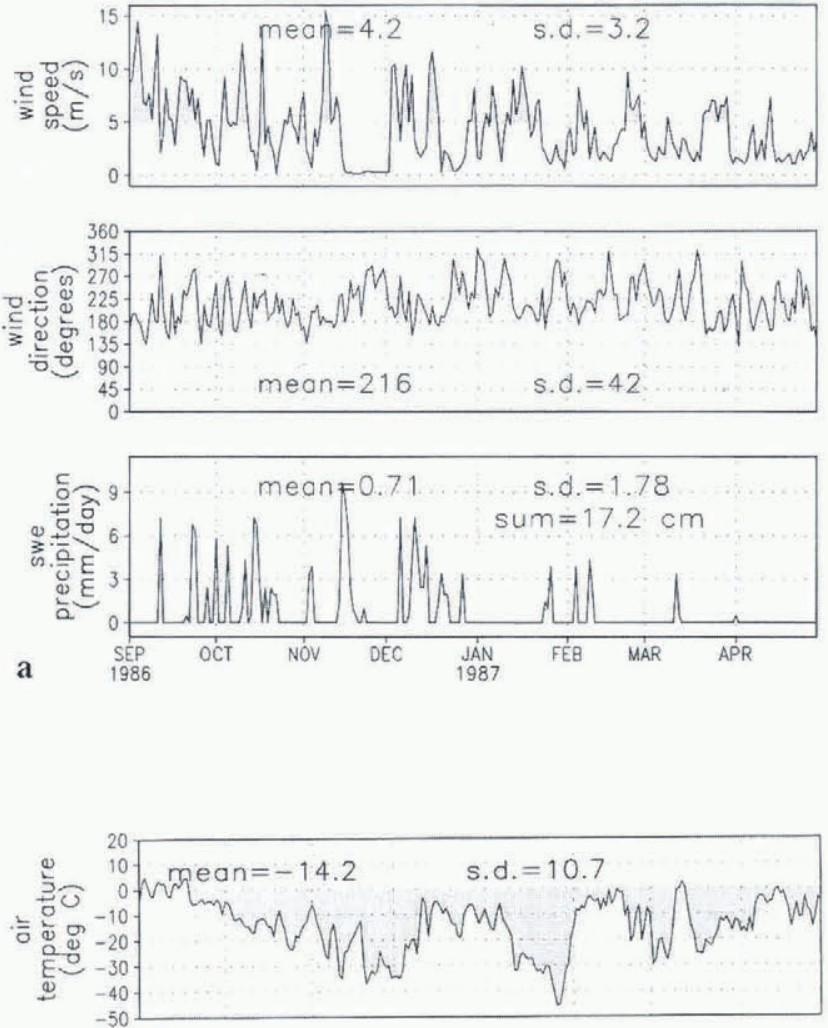

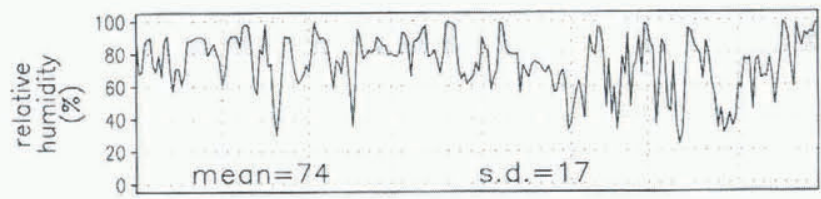
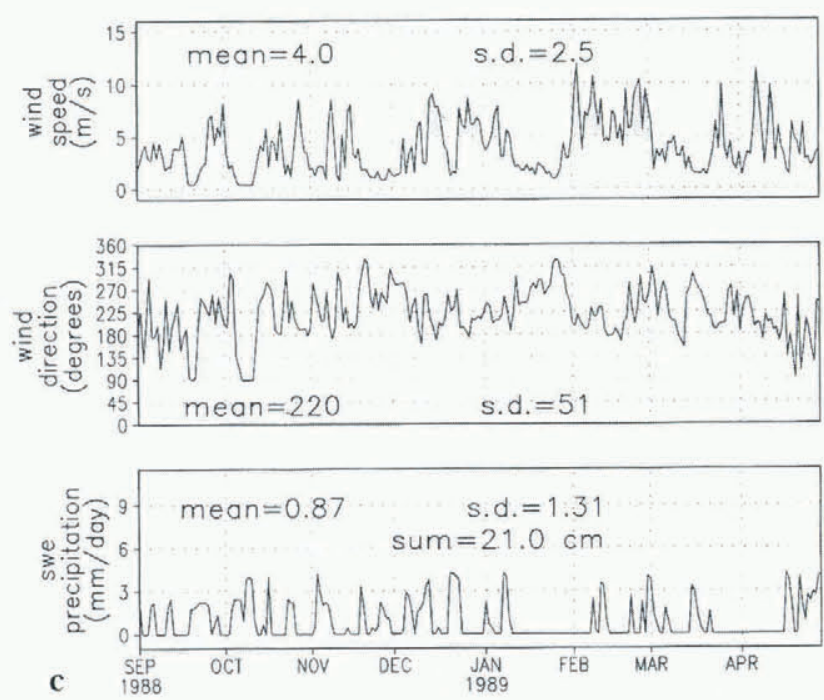

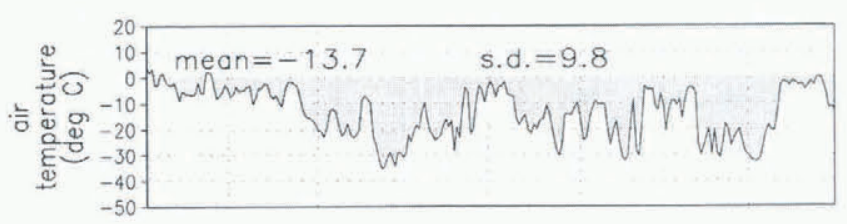

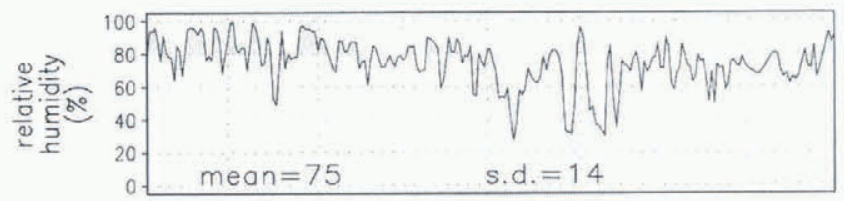
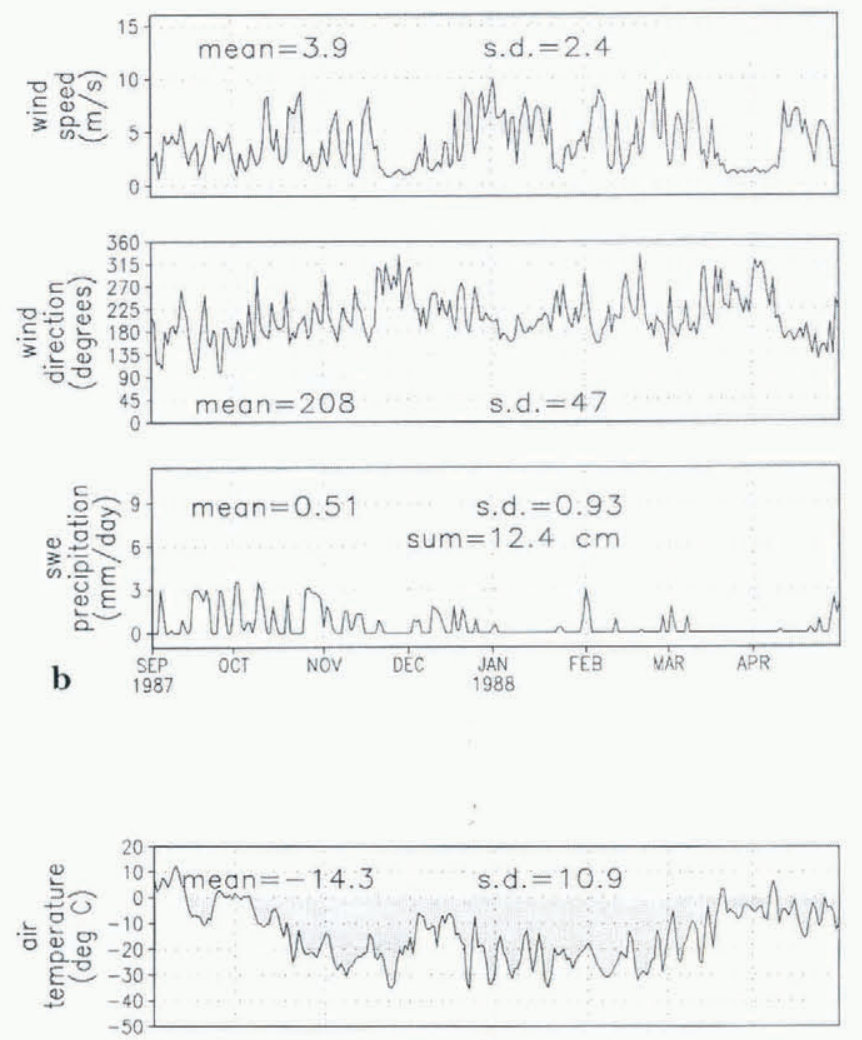

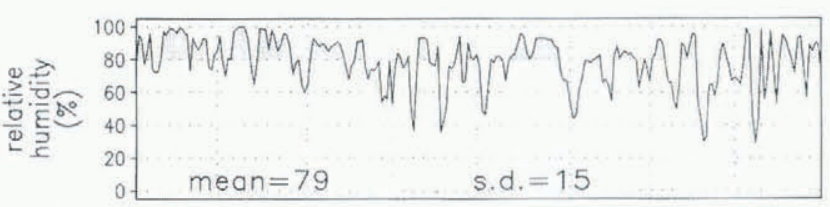

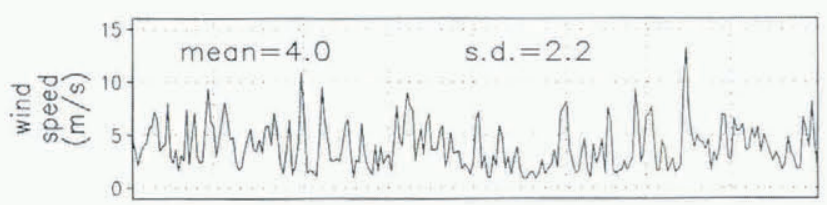
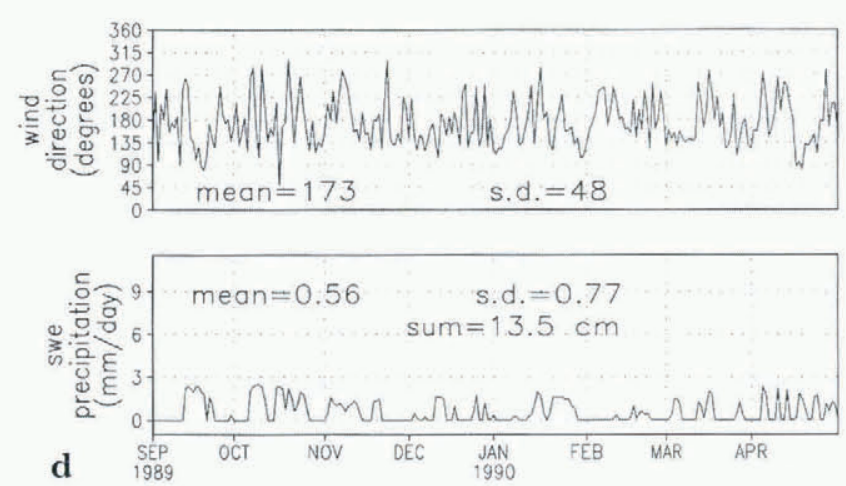

Fig. 8 ( a) September 1986 through April 1987 daily average atmospheric forcing data of air temperature, relative humidity, wind speed and direction, and snow water-equivalent precipitation used in the model simulations. (b) Same as Figure 8a, except for the period September 1987 through April 1988. (c) Same as Figure 8a, except for the period September 1988 through April 1989. (d) Same as Figure 8a, except for the period September 1989 through April 1990. 
Table 2. Summary of atmospheric forcing used in model simulations. All values are compiled from daily averaged meteorological observations

\begin{tabular}{|c|c|c|c|c|}
\hline & 1987 & 1988 & 1989 & 1990 \\
\hline \multicolumn{5}{|l|}{ Air temperature $\left({ }^{\circ} \mathrm{C}\right)$} \\
\hline mean & -14.3 & -13.7 & -14.2 & -14.3 \\
\hline s.d. & 11.0 & 9.8 & 10.7 & 10.9 \\
\hline \multicolumn{5}{|c|}{ Relative humidity ( $\%$ ) } \\
\hline mean & 69 & 75 & 74 & 79 \\
\hline s.d. & 15 & 14 & 17 & 15 \\
\hline \multicolumn{5}{|l|}{ Wind speed $\left(\mathrm{ms}^{-1}\right)$} \\
\hline mean & 4.2 & 3.9 & 4.0 & 4.0 \\
\hline s.d. & 3.2 & 2.4 & 2.5 & 2.2 \\
\hline \multicolumn{5}{|c|}{ Wind direction (degrees true $\mathrm{N}$ ) } \\
\hline mean & 216 & 208 & 220 & 173 \\
\hline s.d. & 42 & 47 & 51 & 48 \\
\hline \multicolumn{5}{|c|}{ Days with wind $>5 \mathrm{~ms}^{-1}$} \\
\hline number & 84 & 76 & 72 & 67 \\
\hline average direction & 199 & 184 & 207 & 172 \\
\hline \multicolumn{5}{|c|}{ Days with wind $>10 \mathrm{~ms}^{-1}$} \\
\hline number & 14 & 0 & 4 & 2 \\
\hline average direction & 193 & - & 233 & 160 \\
\hline \multicolumn{5}{|c|}{ Precipitation $\left(\mathrm{mm} \mathrm{d}^{-1}\right)$} \\
\hline mean & 0.71 & 0.51 & 0.87 & 0.56 \\
\hline s.d. & 1.78 & 0.93 & 1.31 & 0.77 \\
\hline number of events & 49 & 82 & 95 & 111 \\
\hline winter total $(\mathrm{cm})$ & 17.2 & 12.4 & 21.0 & 13.5 \\
\hline
\end{tabular}

Table 3. Observed and model-simulated end-of-winter, snow water-equivalent depths $(\mathrm{cm})$

\section{$1987 \quad 1988 \quad 1989 \quad 1990$}

Imnavait watershed $\left(2.2 \mathrm{~km}^{2}\right)$

Observations

$\begin{array}{llll}10.8 & 7.8 & 15.5 & 10.6\end{array}$

(Hinzman and others, 1996)

Observations

(Benson, unpublished data)

$\begin{array}{lll}11.4 & 9.5 & 15.8\end{array}$

Model

$\begin{array}{lll}11.1 & 8.6 \quad 15.7\end{array}$

11.0

Entire domain $\left(6 \mathrm{~km}^{2}\right)$

\begin{tabular}{|c|c|c|c|}
\hline $\begin{array}{l}\text { Observations } \\
\text { (Benson, unpublished data) }\end{array}$ & 12.0 & 9.6 & 15.8 \\
\hline Model & 12.3 & 9.2 & 16.7 \\
\hline
\end{tabular}

\section{c. Modeled snow distributions}

The simulated end-of-winter snow water-equivalent distribution for 1987, 1988, 1989 and 1990 are shown in Figure 10. Over the gently rolling topography that comprises most of the domain, the model simulates deeper snow on north- and east-facing slopes, with noticeably thinner snow on the south- and west-facing slopes. Since the wind is generally from the south or southwest (Table 2; Fig. 8a-d), these correspond to lee and windward slopes, respectively. The measured snow-distribution maps (Fig. 9) confirm that this is the pattern that develops. Even the trends of snow waterequivalent contours resulting from model simulations are similar to those of the measured distributions. Deep drifts (say over $30 \mathrm{~cm}$ ) are also correctly simulated by the model. The model indicates that most of these lie in the lee of the steep topography located in the northern quarter of the domain, a fact confirmed by the field measurements. For example, the model predicts an excess of $30 \mathrm{~cm}$ snow water equivalent at a location where we have observed drift accumulation since 1985. In this location (labeled "S2-Drift" in Figure 7), a large wedge-shaped accumulation, ranging up to $2 \mathrm{~m}$ thick, forms every winter. Overall, the model indicates that these drift accumulations of over $30 \mathrm{~cm}$ snow water equivalent covered $1 \%, 1 \%, 2 \%$ and $1 \%$ of the domain in 1987, 1988, 1989 and 1990, respectively. These areal coverages compare well with the $2 \%, 1 \%, 2 \%$ and $1 \%$ indicated by the observed distributions.

The model simulations can also be used to assess the various factors producing the end-of-winter snow distribution. The individual domain-averaged, winter-total contributions of precipitation, saltation, turbulent-suspension and sublimation are shown in Table 4 . The sign of the values in Table 4 indicates either accumulation $(+)$ or loss $(-)$ of water from the domain. Precipitation minus sublimation, minus the transport out of the domain by saltation and suspension, equals the depth of snow on the ground at the end of winter. As an example, in $1987,71 \%$ of the winter precipitation remained on the ground, $22 \%$ was returned to the atmosphere through sublimation, and $5 \%$ and $2 \%$ was transported out of the domain by saltation and suspension, respectively. The spatial distributions of each of these waterbalance components are displayed in Figures 11, 12 and 13.

Inconsistencies between modeled and measured snow distributions appear to arise, at least in part, from inaccuracies in the wind field computed by Equation (19). One type of inconsistency is where the modeled snow depth is correct but its location is shifted laterally with respect to the measured distribution. The precise character of increasing and decreasing wind speed as it flows over a subtle ridge is difficult to capture with the simple wind model. In contrast, the influence of the flow over a sharp ridge, such as the "S2" drift trap in the north of the domain, is easy to simulate and the model consistently locates the resulting deep drifts correctly. Equation (19) is also inadequate to simulate the wind field required to produce the observed deep accumulation located at approximately $2.3 \mathrm{~km}$ north and $1.7 \mathrm{~km}$ east, occurring in all four winters (cf. Figs 9 and 10). This accumulation forms because the wind coming from the south or southwest "feels" the relatively large topographic obstruction ahead and, as the streamlines begin to separate from the snow surface, the shear velocity is reduced and snow is deposited much like the accumulation upwind of a snow fence (Mellor, 1965; Tabler, 1980; Liston and others, 1993a, b). To simulate such flow features requires a more sophisticated and computationally expensive wind model.

\section{ANALYSIS OF MODEL SIMULATIONS}

Based on data collected for the Imnavait Creek watershed between 1985 and 1993 (Kane and others, 1991; Hinzman and others, 1996), the period over which we ran our simulations includes two "average" accumulation winters (1987 and 1990), one "light" accumulation winter (1988) and one "heavy" accumulation winter (1989) (Table 4). For each of these winters we have calculated, from model simulations, the area-averaged snow water equivalent remaining on the 

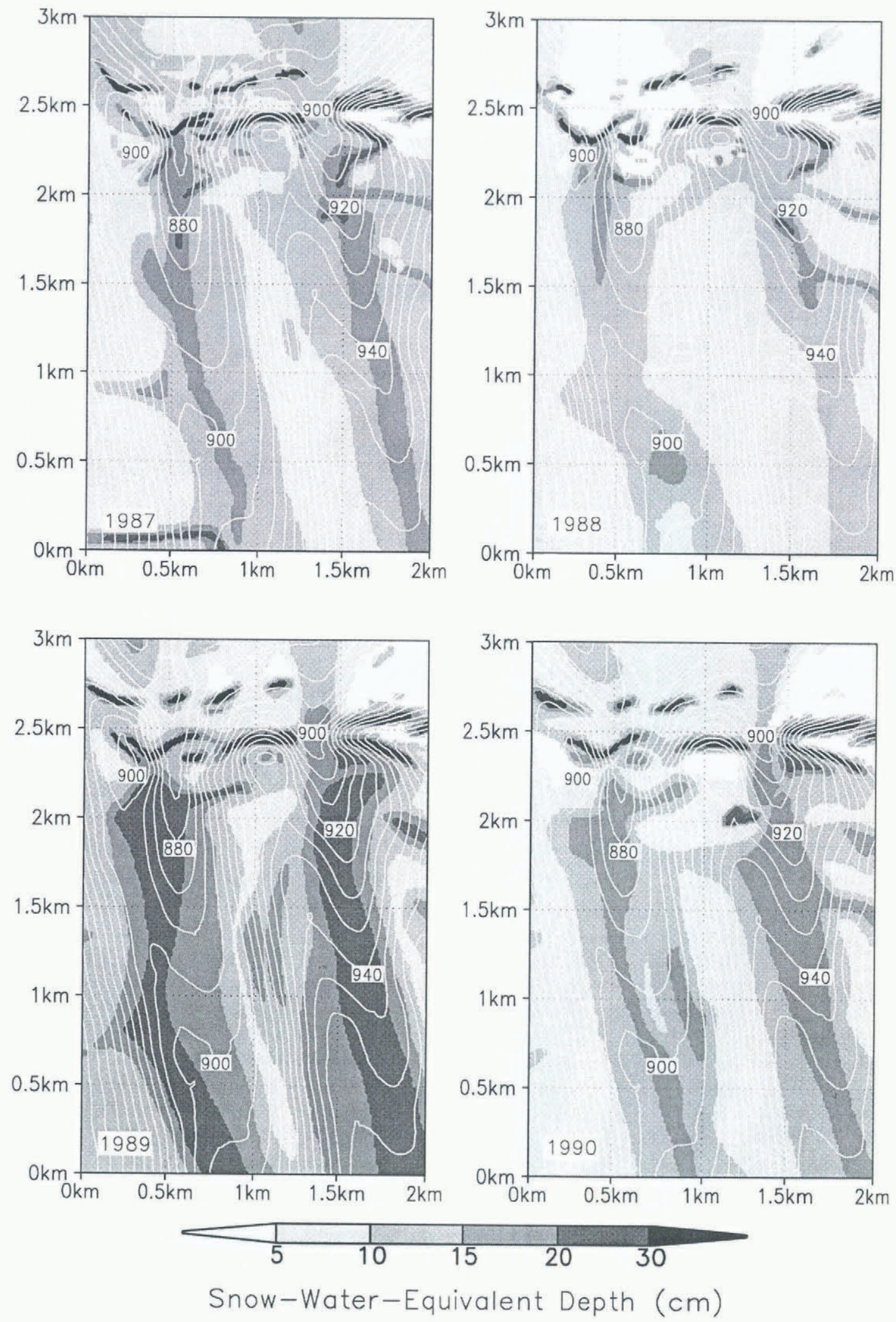

Fig. 9. Observed snow water-equivalent distributions (cm) for the winters 1987, 1988, 1989 and 1990 in the Imnavait Creek area (Liston, 1986; Hinzman and others, 1996; Benson, unpublished data).

ground at the end of winter, and how much snow (in snow water-equivalent units) has been lost from the domain by sublimation, saltation and turbulent-suspension (Table 4). We have also mapped how these gains and losses were distributed over the domain (Figs 11, 12 and 13). The results indicate that, averaged over the domain, 9-22\% of the totalwinter precipitation was returned to the atmosphere by sublimation. This range is comparable to values found by Pomeroy and Gray (1995) for the Canadian Prairies and is large enough to impact the end-of-winter distributions sig- nificantly. In 1987, for example, there was $27 \%$ greater precipitation than in 1990 , but at the end of winter, both the area-averaged snow water equivalent (Table 4) and the snow-distribution patterns (Figs 9 and 10) were similar. The primary cause leading to these similar end-of-winter conditions was sublimation losses, which were 2.9 times greater in 1987 than in 1990. The greater amount of sublimation in 1987 was the result of more days with average wind speeds in excess of $10 \mathrm{~m} \mathrm{~s}^{-1}$ (Table 2). As a further example, the precipitation in 1988 and 1990 were nearly equal but, 

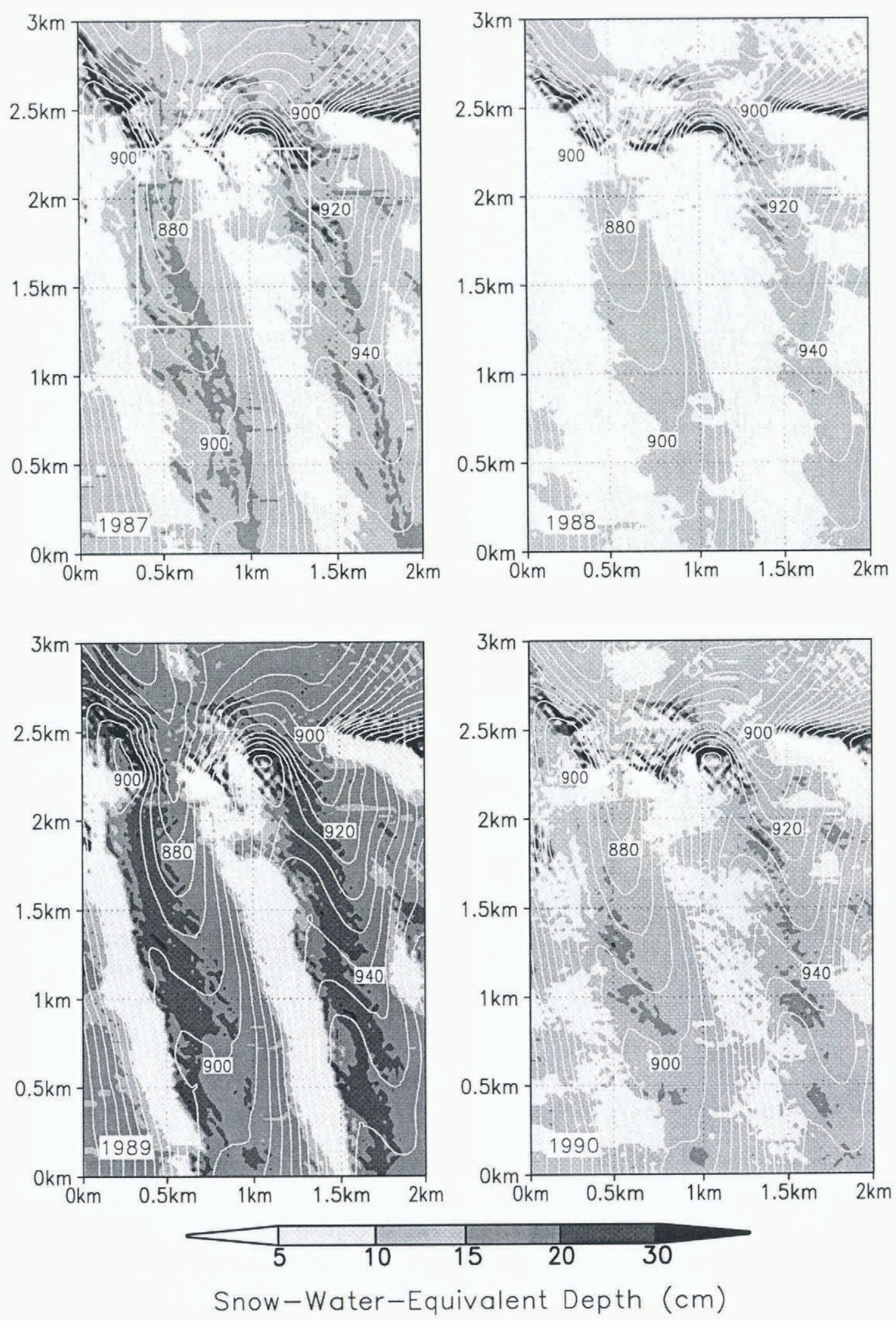

Fig. 10. Model-simulated end-of-winter snow water-equivalent distributions (cm) for the winters 1987, 1988, 1989 and 1990. Also shown is a $1 \mathrm{~km}$ box in the 1987 panel outlining the domain coincident with Figure 14.

with sublimation losses running nearly twice as high in 1988, the 1988 end-of-winter snow water-equivalent values were notably lower. The 1988 sublimation losses were large enough to change the winter snow-accumulation classification from "average" to "light" (Table 4). In this case, the number of days having average wind speeds in excess of $10 \mathrm{~m} \mathrm{~s}^{-1}$ was not greatly different between the two winters, but in 1988 the daily average wind speed stayed almost continuously above $5 \mathrm{~m} \mathrm{~s}^{-1}$ through January and part of Febru- ary (Fig. 8b), while in 1990, higher wind speeds were limited to isolated events (Fig. 8d). During the same period, the 1988 temperature was higher and the relative humidity lower, both conditions that favor sublimation.

Model simulations indicate that maximum sublimation losses were located on south- and west-facing slopes (Fig. 11), in the same locations where saltation and suspension-transport losses were highest. Since the sublimation rate is tied to both the saltating and suspended mass flux through Equation 
Table 4. Domain-averaged, winter-total, snow water-equivalent quantities $(\mathrm{cm})$ from model simulations

\begin{tabular}{|c|c|c|c|c|}
\hline & 1987 & 1988 & 1989 & 1990 \\
\hline Precipitation input & 17.2 & 12.4 & 21.0 & 13.5 \\
\hline $\begin{array}{l}\text { Depth on ground } \\
\text { classification } \\
\text { ( } \% \text { of precipitation) }\end{array}$ & $\begin{array}{c}12.3 \\
\text { Average } \\
(71)\end{array}$ & $\begin{array}{c}9.2 \\
\text { Light } \\
(74)\end{array}$ & $\begin{array}{c}16.7 \\
\text { Heavy } \\
(80)\end{array}$ & $\begin{array}{c}11.5 \\
\text { Average } \\
(86)\end{array}$ \\
\hline $\begin{array}{l}\text { Sublimation loss } \\
\text { ( } \% \text { of precipitation) }\end{array}$ & $\begin{array}{l}-3.8 \\
(22)\end{array}$ & $\begin{array}{l}-2.5 \\
(20)\end{array}$ & $\begin{array}{c}-3.8 \\
(18)\end{array}$ & $\begin{array}{c}-1.3 \\
(9)\end{array}$ \\
\hline $\begin{array}{l}\text { Saltation loss } \\
\text { ( } \% \text { of precipitation) }\end{array}$ & $\begin{array}{l}-0.8 \\
(5)\end{array}$ & $\begin{array}{c}-0.7 \\
(6)\end{array}$ & $\begin{array}{l}-0.5 \\
(2)\end{array}$ & $\begin{array}{l}-0.6 \\
(4)\end{array}$ \\
\hline $\begin{array}{l}\text { Suspension loss } \\
\text { ( } \% \text { of precipitation })\end{array}$ & $\begin{array}{l}-0.3 \\
(2)\end{array}$ & $\begin{array}{l}0.0 \\
(0)\end{array}$ & $\begin{array}{l}0.0 \\
(0)\end{array}$ & $\begin{array}{l}0.1 \\
(1)\end{array}$ \\
\hline
\end{tabular}

(18) (also see the Appendix), this is expected; these windward slopes are where transport processes are most vigorous (Figs 12 and 13). Data collected during the winter of 1995-96 from a $1 \mathrm{~km}$ by $1 \mathrm{~km}$ section within the model domain support the simulations. For this area, the snow-depth distribution was mapped on 6 November 1995, and again on 26 March 1996. The difference in depth between the two observation times is shown in Figure 14; the domain covered by Figure 14 corresponds to the $1 \mathrm{~km}$ box drawn in the 1987 panel of Figure 10. The observed pattern in Figure 14 is strikingly similar to those found in Figure 10, and indicates that on the windward slope little change in depth occurred during the 5 month period, while on lee and valley-bottom slopes, increases in snow depth as large as $55 \mathrm{~cm}$ occurred. During the same period, snowfall was about average with numerous snowfall events. The minimal windward-slope depth changes and small downwind (to the north-northeast) snow-depth enhancement, in conjunction with the model results, suggests that the majority of winter precipitation falling on windward slopes was lost by sublimation.

The saltation-transport patterns (Fig. 12) highlight the importance of topography in controlling this process. During the years 1987, 1988 and 1989, snow was generally removed from south- and west-facing slopes and deposited on lee slopes, collecting in large amounts in the "S2" and other drift-accumulation areas. In contrast, in 1990, when the wind tended to blow more from the southeast (Table 2) and roughly parallel with the ridge and valley lines, there was virtually no change in depth due to saltation over most of the gently rolling topography of the domain (Fig. 12). At the same time, the "S2" and other drift areas continued to accumulate snow. These drift-accumulation areas are much smaller than their upwind supply zones, and are thus able to acquire significant accumulations while the supply-area depths change only slightly.

The patterns of snow-depth change resulting from suspended transport (Fig. 13) are similar to those of saltation, with appreciable amounts transported in 1987, 1989 and 1990. In many regions of the domain, for these 3 years, the suspended-transport amounts exceed those of saltation (cf. Figs 12 and 13). As indicated by Figure 5, this behavior is expected at higher wind speeds and is consistent with findings by Pomeroy (1989), who concluded that, as wind speed increases, suspension becomes the dominant transport mechanism. In 1988, when the daily average wind speed never exceeded $10 \mathrm{~ms}^{-1}$ (Table 1), transport due to suspension was minimal (Fig. 13).

\section{DISGUSSION}

The snow-transport model has been used to map the redistribution of snow (or snow water equivalent) by wind over a realistic landscape consisting of variable vegetation, ridges and valleys. The resulting end-of-winter snow distribution maps (Fig. 10) compare well with ones based on measurements (Fig. 9). The model could produce accurate maps, yet still have errors in its sublimation, suspension and saltation routines. However, these routines are based on well-researched process studies and, where we have been able to compare individual simulated transport components with observations (e.g. Fig. 14), the agreement is good. Where differences between the measured and simulated maps exist, they appear, in part, to be largely due to inaccuracies in the simulated wind field. High-quality atmospheric forcing (precipitation, wind speed and direction, air temperature and relative humidity) are required to simulate the observed snow distributions but are not always available.

Each component of the model is necessary to produce the correct end-of-winter snow distribution but in the Arctic the sublimation routine is crucial. In some regions of Imnavait Creek, sublimation removed as much as half of the snow on windward slopes (Figs 10 and 11). This suggests that a substantial amount of the large-scale distribution patterns shown in Figures 9 and 10, and possibly throughout the Arctic, are the result of sublimation. If so, the finding has practical implications regarding the origin of perpetually snowfree zones in the Arctic. For example, the snow-free valleys of the Brooks Range in Alaska (e.g. the Itkillik, the Anaktuvak and the Atigun), where katabatic down-valley winds are frequent, may be the result of blowing-snow sublimation, not a lack of winter precipitation nor the transport of snow out of the valley. In the coastal regions of Arctic Alaska, where wind speeds are generally much higher, sublimation losses are expected to be greater than those found in Imnavait. As an example, increasing the wind speed from $4.0 \mathrm{~m} \mathrm{~s}^{-1}$ (the measured Imnavait 4 year winter average) to $5.4 \mathrm{~m} \mathrm{~s}^{-1}$ (the Barrow winter average; Hare and Hay, 1974), increases the 4 year average sublimation loss from $17 \%$ to $27 \%$ of the winter precipitation.

Using the model to partition the end-of-winter snow distribution into its individual components also provides insight into deep-drift accumulation processes. Drifts form even in years when saltation or suspension transport are relatively small. This is because drifts occupy a small area compared to their source area. In addition, once the snow is trapped in the drift, it suffers virtually no loss from sublimation (Fig. 11), ensuring the snow depth remains high.

Topography dominates the wind redistribution of snow in a way that makes the general snow-distribution patterns more sensitive to changes in wind direction than wind speed. The distribution patterns (Figs 9 and 10) are similar as long as the average winter wind comes from a generally fixed direction but any significant shift in wind direction relative to topography alters the distribution pattern. As part of model-sensitivity simulations we have imposed wind-direction perturbations ranging from $\pm 15^{\circ}$ to $\pm 180^{\circ}$ away from the observed wind directions. In these simulations, the patterns of snow depth, saltation, suspension and 

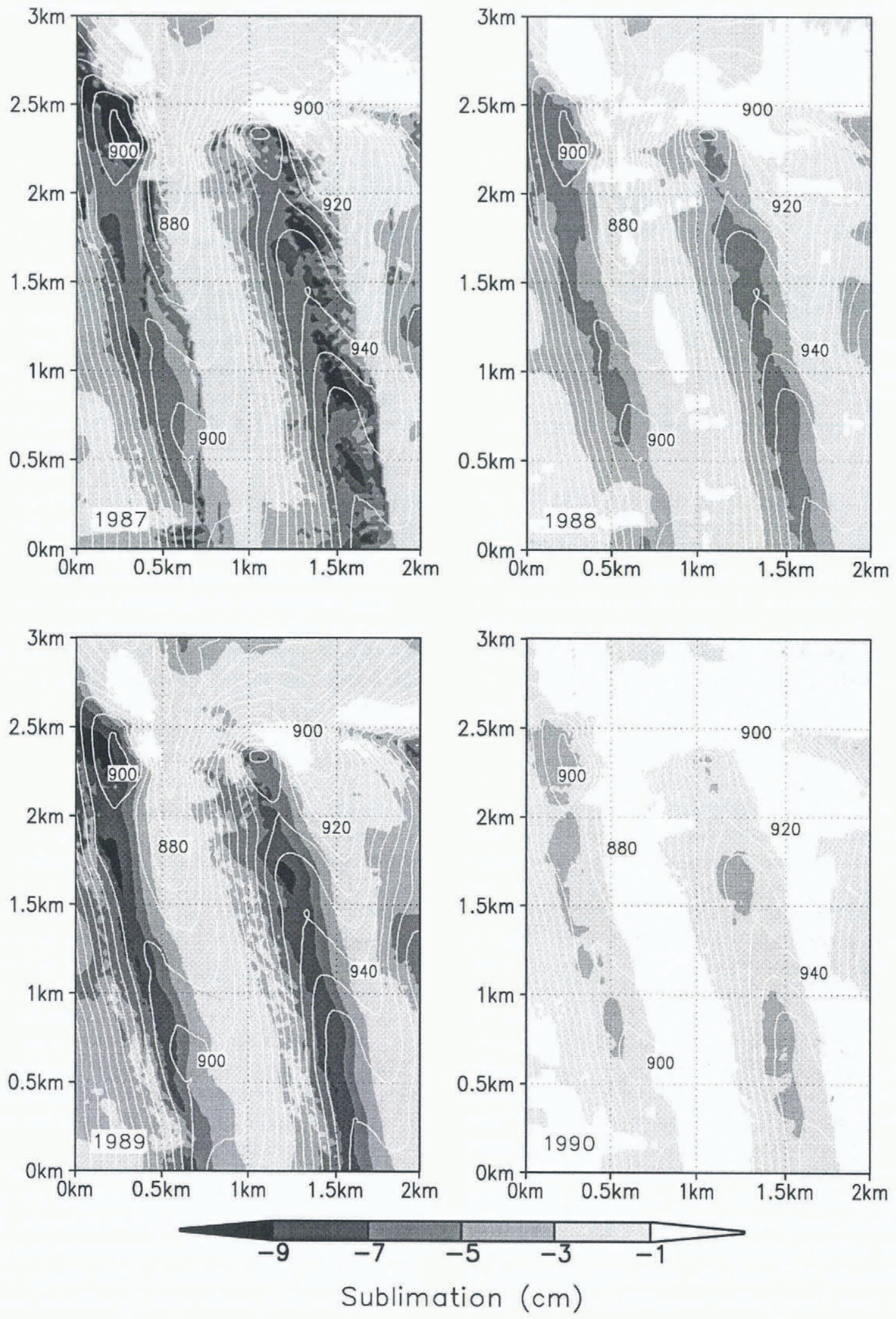

Fig. 11. Total winter sublimation, in snow water-equivalent depth (cm) for the simulations given in Figure 10.

sublimation can all be modified significantly, depending on the relationship between the new wind direction and topography; the most dramatic snow-pattern changes occur when the new wind direction changes a windward slope to a lee slope, or a lee slope to a windward slope. Application of the model suggests that a realistic computation of the windspeed and direction field is a dominating factor leading to a successful snow-distribution simulation, and that the simulated snow distribution closely resembles the integrated winter wind field occurring above some threshold wind speed.

\section{a. Model deficiencies}

The model performs reasonably well in our test cases but it is still a simple approximation to a complex natural system. Model deficiencies can be divided into two areas: those that arise because of limitations and constraints on input data and those that arise due to erroneous assumptions, oversimplifications or errors in the model snow-transport physics. The former limitations are thought to be more severe than the latter.

As an example, if our topographic data do not resolve a 

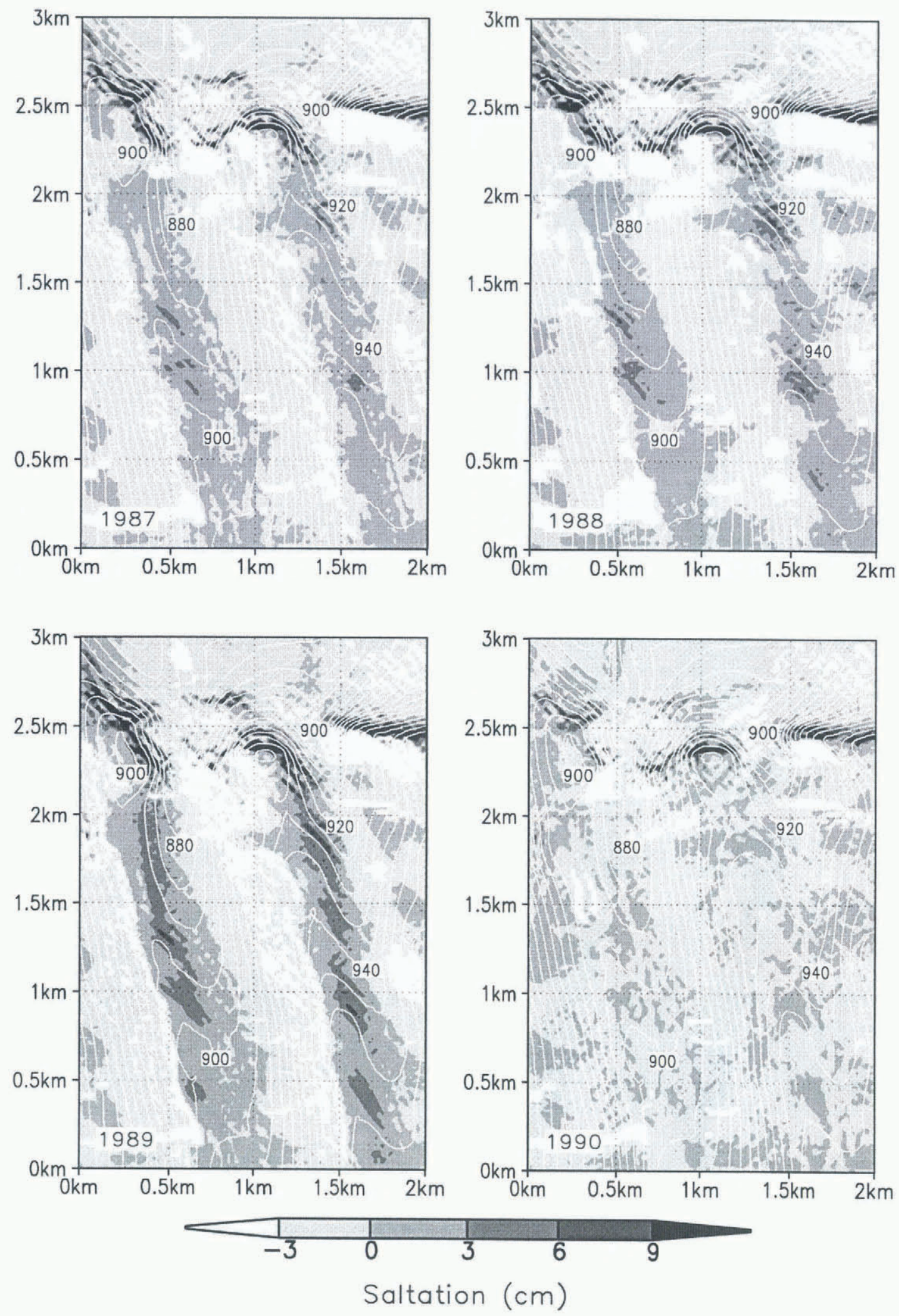

Fig. 12. Total winter snow-depth changes resulting from saltation, in snow water-equivalent depth (cm) for the simulations given in Figure 10.

hill or bump, the model cannot accumulate snow in the lee of that bump. Likewise, if our meteorological input fails to resolve brief but intense periods of snowfall or high winds, then the actual drift accumulation or erosion will not be simulated. In addition, the simple model used to distribute wind over the domain may be inadequate for many topographic profiles. A more detailed and sophisticated wind model, one that could handle flow over a large range of topographic configurations, including three-dimensional flow over sharp ridges, peaks and valleys, or flow around solid and porous obstructions such as trees, snow fences and rock outcrops, would improve the results. However, the trade-off is increased computational complexity, and spatially and temporally detailed input data would still be required.

The choice of model grid size will influence the resulting simulation. In general, the physics and assumptions adopted in the model will not be violated if the grid size is reduced or increased, say within a range of $1 \mathrm{~m}$ to a few hundred meters, 

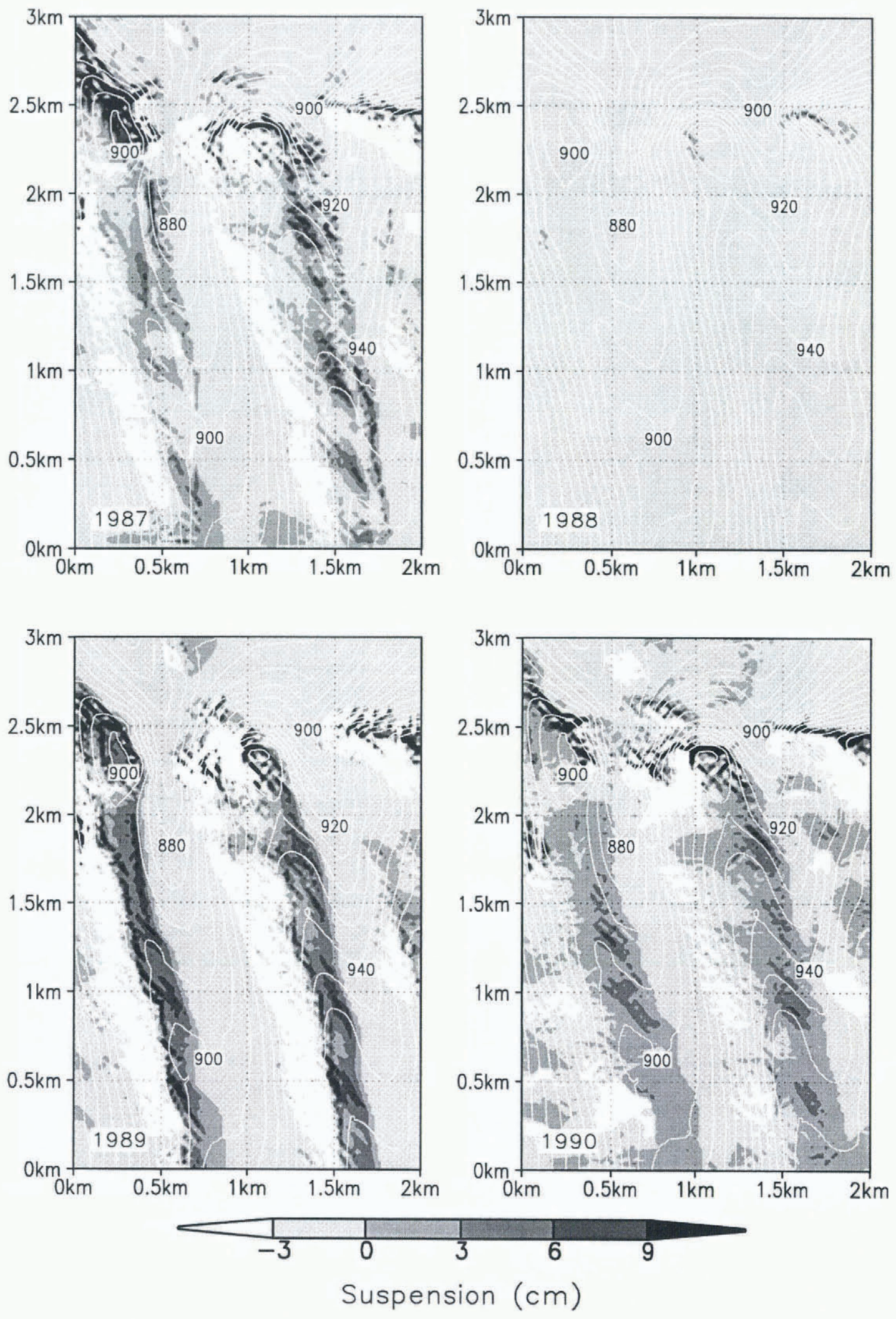

Fig. 13. Total winter snow-depth changes resulting from suspension, in snow water-equivalent depth (cm) for the simulations given in Figure 10.

but the different resolutions will have certain consequences. Increasing the grid size in the current study leads to reduced definition of the "S2-type"drifts. If the resolution exceeds the general scale of that feature, it will be lost by the simulation entirely, or at least smoothed to the extent that it is not recognizable in its original form. For the domain considered here, a computational grid of $100 \mathrm{~m}$ would be quite appropriate and produce outputs similar to those presented here, with the expected loss of the deeper drifts (e.g. we are running the model successfully for a $230 \mathrm{~km}$ by $85 \mathrm{~km}$ domain, using a $100 \mathrm{~m}$ grid, that encompasses the Kuparuk River basin in Arctic Alaska). When a high-resolution, $1 \mathrm{~m}$ grid is used over an area like the "S2" drift, a sharp decrease in shear velocity will occur just over the topographic lip. Large snow deposits will form in the lee of the lip, and in time this snow may be higher than the elevation of the gridcell immediately upwind. In Nature, the wind would notice this snow bump and transport it farther downwind, but in the model this 


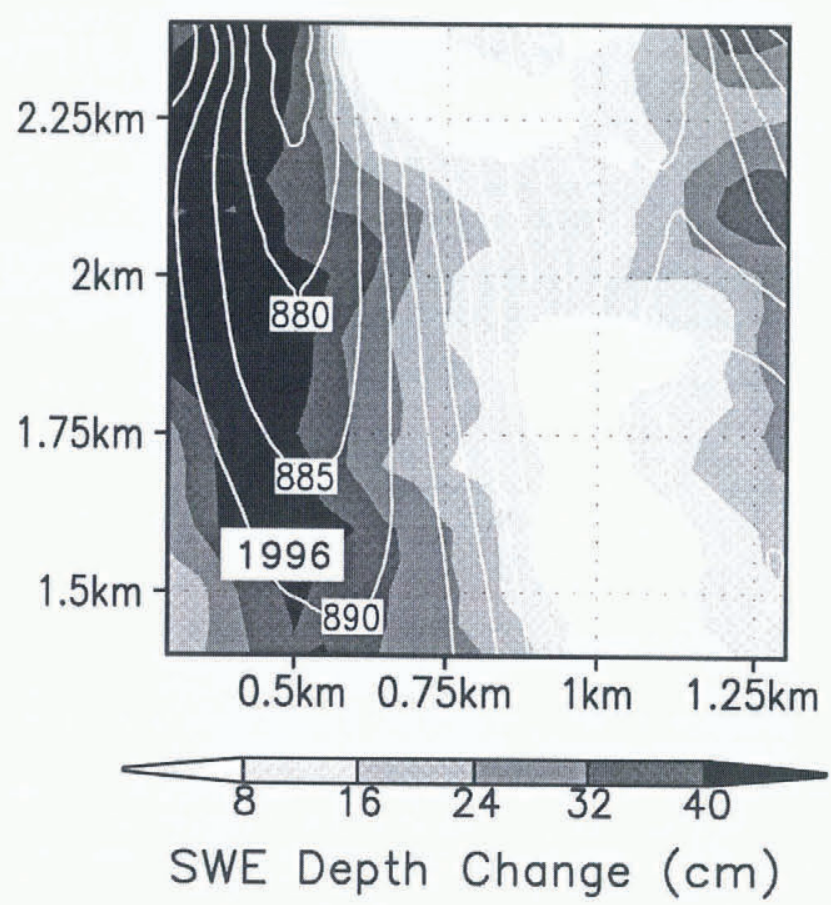

Fig. 14. The difference between snow depth measured on 6 November 1995 and 26 March 1996 for a domain corresponding to the $1 \mathrm{~km}$ box drawn in the 1987 panel (Fig. 10).

must be done by including a parameterization that redistributes the snow downwind. An alternative approach is to adjust the wind field as the "snow topography" evolves (Liston, 1991; Liston and others, 1993a; Sundsbo, 1997). This would replicate the natural system more accurately and would be a significant improvement in places where large changes in surface topography occur due to snow deposition. As snow accumulates, the drift trap should evolve towards an equilibrium profile. Observational studies have found an equilibrium snow-embankment angle of approximately $17 \%$ (Finney, 1939; Tabler, 1975b), below which snow no longer accumulates, suggesting the wind-shear velocity is uniform over the embankment. Such a feature should be reproduced as part of a wind-modeling system that adjusts to the "snow topography".

Problems with our physical formulations may also adversely affect the simulations. These include (in decreasing order of severity):

(1) Actual snow density and threshold shear velocity vary both temporally and spatially but, as a first approximation, the model assumes both to be constant in time and space (Table 1). In order to test the effect of this simplification, a threshold shear-velocity parameterization was implemented. This parameterization kept track of the amount and location of relatively new snow and redistributed or old snow, assigning different threshold shear velocities to each. In this scheme, the new-snow depth increased with each precipitation event, then decreased following the event according to a predefined densification rate. As the snow densified, its threshold shear velocity increased. The parameterization did not lead to any measurable improvement in the accuracy of the modeled snow cover and the increase in computational complexity did not seem justified. This result suggests that in the Arctic, it is acceptable to use a spatially and temporally constant threshold shear velocity, because the threshold shear velocity changes very slowly in the relatively low air temperatures. A more complex formulation would be required for model implementations in warmer climates.

(2) Natural fluctuations in wind speed and direction produce transport fluxes that may not be in equilibrium with the average wind speed. Our model does not account for such non-steady conditions. Related to this is the assumption that the concentration profile of the suspended snow load is in local equilibrium with the saltation-layer concentration. This is also inappropriate under certain conditions. Under high wind speeds, for example, when snow is transported over a sharp ridge, the turbulent suspended plume can be transported far beyond the ridge crest, while the saltation-layer concentration falls off rapidly with the decrease in wind-shear velocity. In the model, the reduced near-surface wind speed just over the ridge crest leads to unrealistically low particle concentrations in the plume above, and consequently unrealistically high snow depositions.

(3) As indicated in the Appendix, feedbacks between the sublimation rate and the humidity field are not accounted for. We intuitively expect that sublimation should lead to increased atmospheric moisture and this in turn will decrease the sublimation rate. However, using a model that accounts for these feedbacks, and additional interactions with turbulent moisture and momentum fluxes, R. Bintanja (personal communication, 1998) has found that the absolute-humidity increase, resulting from snowparticle sublimation, is compensated for by increased upward moisture transport out of the surface layer. Clearly, such interactions need to be addressed in a model attempting to simulate realistically the details of blowingsnow sublimation. In addition, these results suggest that the quantities produced by our simple sublimation submodel may be in error but magnitude and direction of the potential error is unknown.

(4) The model assumes a vertical distribution of mean particle size. In reality, the range of particle sizes within the snow-transport profile can vary by an order of magnitude (Budd, 1966; Schmidt, 1982). This spectrum of sizes is expected to influence many of the processes associated with turbulent kinetic energy and moisture transfers occurring during snow transport (Déry and Taylor, 1996) but we do not know how it might affect the modeled results.

\section{CONCLUSIONS}

A physically based numerical snow-transport model (SnowTran-3D) has been developed and used to simulate the redistribution of snow by wind in variable topography. The model describes interactions between the atmosphere, land and snow cover in treeless areas such as tundra, prairie and alpine landscapes. The model includes an accounting of (1) the capturing of snow by vegetation, (2) non-equilibrium transport by saltation and turbulent suspension, (3) the influence of saltation on surface-shear velocity, (4) sublimation of the blowing and drifting snow and (5) erosion and deposition.

Comparison of model simulations with 4 years of Arctic Alaska field observations shows the model is able to describe the general snow-distribution features. In addition, the 
model can be used to quantify moisture losses due to sublimation during snow-transport events. In the foothills north of the Brooks Range in Arctic Alaska, these losses were found to range between $9 \%$ and $22 \%$ of the precipitation input. In the coastal regions of Arctic Alaska, where wind speeds are generally much higher, the model suggests that sublimation will be greater.

In the current study, the threshold shear velocity has been assumed to be a pre-defined constant which does not evolve in time or space. While we know that this is a crude approximation to the natural system, attempts to introduce more complex and physically realistic parameterizations of this important variable did not lead to improved simulations, at least within the spatial and temporal resolution and quality of our validation datasets. One reason why we are able to use this simple approximation successfully is that, during the winter months, temperatures in Arctic Alaska are low and the snow maintains a nearly constant surface-shear strength. To apply this snow-transport model in a region where near-freezing temperatures are a regular occurrence, or to follow the detailed evolution of individual storm events, a more realistic formulation of the threshold shear velocity, which includes an accounting of temperature, wind, precipitation and snow-transport histories, would be required.

The ability of the snow-transport model to reproduce the observed snow distributions and moisture fluxes is strongly dependent upon the simulated wind-flow field. While the current wind-field representation was found to be adequate, the transport model would benefit from a more general wind model which would allow straightforward application to other, generally more complex, landscapes.

The success of this snow-transport model suggests that it is a viable complement to labor-intensive field snow-mapping methods. Using standard meteorological observations, and topography and vegetation datasets, in conjunction with limited end-of-winter mean snow water-equivalent observations, the snow-cover distribution can be simulated. The physically based nature of the model allows for its application in a wide variety of climates and allows the ability to address issues of changing climate. With only a few modifications to account for processes occurring at higher temperatures, the model should be applicable in a wide range of landscapes and regions throughout the world.

\section{ACKNOWLEDGEMENTS}

The authors wish to thankJ. Holmgren, C. Benson, L. Hinzman, E. Lilly, N. Auerbach, E.Pyne, D. Solie, M. Zukowsik and R. Gieck for their efforts in collecting and supplying data which supported this research. In addition, we are grateful for the critique of this work provided by R. A. Schmidt, R. Tabler, R. Kind and an anonymous reviewer. This work was supported by U.S. National Science Foundation contract OPP-94-15386.

\section{REFERENCES}

Benson, C. S. 1982. Reassessment of winter precipitation on Alaska's Arctic Slope and measurements on the flux of wind blown snow. Fairbanks, Alaska, September, Geophysical Institute, University of Alaska. (Report 288.)

Benson, C. S. and M. Sturm. 1993. Structure and wind transport of seasonal snow on the Arctic slope of Alaska. Ann. Glaciol., 18, 261-267.

Berg, N. H. and N. Caine. 1975. Prediction of nalural snowdrift accumulation in alpine areas. Final report to Rocky Mountain Forest and Range Experiment Sta- tion. Boulder, CO, University of Colorado. Department of Geography; Rocky Mountain Forest and Range Experiment Station. (USFS 19388-CA.)

Bintanja, R. 1998a. The interaction between drifting snow and atmospheric turbulence. Ann. Glaciol., 26, 167-173.

Bintanja, R. 1998b. The contribution of snowdrift sublimation to the surface mass balance of Antarctica. Ann. Glaciol., 27, 251-259.

Budd, W. F., R. J. Dingle and U. Radok. 1966. The Byrd Snow Drift Project: outline and basic results. In Rubin, M. J., ed. Studies in Antarctic meteorology. Washington, DC, American Geophysical Union, 71-134. (Antarctic Research Series 9.)

Burridge, D. M. and A.J. Gadd. 1974. The Meteorological Office operational 10 level numerical weather prediction model (December 1974). Bracknell, Berks., British Meteorological Office. (Technical Notes 12 and 48.)

Déry, S. J. and P. A. Taylor. 1996. Some aspects of the interaction of blowing snow with the atmospheric boundary layer. Hydrol. Processes, 10, 1345 1358.

Duffie, J. A. and W. A. Beckman. 1994. Solarenergy thermal processes. New York, Wiley and Sons.

Evans, B. M., D. A. Walker, C. S. Benson, E. A. Nordstrand and G. W. Petersen. 1989. Spatial interrelationships between terrain, snow distribution and vegetation patterns at an Arctic Foothills site in Alaska. Holartic Ecology, $12(3), 270-278$.

Finney, E. A. 1939. Snow drift control by highway design. In . Michigan State College Engineering Experiment Station, (Bulletin 86.)

Fleagle, R.G. and J.A. Businger. 1980. An introduction to atmospheric physics. New York, Academic Press.

Goodison, B. E. 1981. Compatibility of Canadian snowfall and snow cover data. Water Resour. Res., 17 (4), 893-900.

Greeley, R. and J. D. Iversen. 1985. Wind as a geological process on Earth, Mars, Venus and Titan. Cambridge, Cambridge University Press.

Hall, D. K. 1988. Assessment of Polar climate change using satellite technology. Rev. Geophys., 26 (1), 26-39.

Hare, F. K. and J. E. Hay. 1974. The climate of Canada and Alaska. In Bryson, R. A. and F. K. Hare, eds. Climates of North America. Amsterdam, Elsevier Scientific Publishing Co., 49-192. (World Survey of Climatology 11.

Hinzman, L. D., D. L. Kane, C. S. Benson and K. R. Everett. 1996. Energy balance and hydrological processes in an Arctic watershed. In Reynolds, J. F. and J. D. Tenhunen, eds. Landscape function: implications for ecosystem response to disturbance. A case study in Arctic tundra. New York, Springer-Verlag, 131-154. Ecologic Studies Series 120.

Iversen, J. D. 1981. Comparison of wind-tunnel model and full-scale snow fence drifts. Journal of Wind Engineering and Industrial Aerodynamics, 8, $231-249$.

Kane, D. L., L. D. Hinzman, C. S. Benson and G. E. Liston. 1991. Snow hydrology of a headwater Arctic basin. 1. Physical measurements and process studies. Water Resour. Res., 27 (6), 1099-1109.

Kikuchi, T. 1981. A wind tunnel study of the aerodynamic roughness associated with drifting snow. Cold Reg. Sci. Technol., 5 (2), 107-118.

Kind, R. J. 1976. A critical examination of the requirements for model simulation of wind-induced erosion/deposition phenomena such as snow drifting. Atmos. Environ., 10 (3), $219-227$.

Kind, R. J. 1992. One-dimensional aeolian suspension above beds of loose particles - a new concentration-profile equation. Atmos. Environ., 26A (5), 927-931.

Kobayashi, D. 1972. Studies of snow transport in low-level drifting snow. Contrib. Inst. Low Temp. Sci., Ser. A 24, 1-58.

Kobayashi, S. 1979. Studies on interaction between wind and dry snow surface. Contrib. Inst. Low Temp. Sci., Ser. A 29, 1-64.

König, M. 1997. Mapping snow distribution in the Alaskan Arctic using air photos and topographical relationships. (M.Sc. thesis, University of Alaska, Fairbanks, AK.

Kreutz, W., K. Schubach and W. Walter. 1955. Untersuchungen über die geländeklimatischen Verhältnisse der Gemarkung Dieburg und über Wind- und Temperaturverhaltnisse in den Germarkungen Hausen und Langenseifen im Unteraunuskrieis mit der Zielsetzung ihrer Verbesserung durch Windschutzbedurftigkeit. Archiv für Raumf. Hessen., 1, 1-46.

Lee, L.W. 1975. Sublimation of snow in turbulent atmosphere. (Ph.D. thesis, University of Wyoming, Laramie, WY.

Liston, G. E. 1986. Seasonal snow cover of the foothills region of Alaska's Arctic Slope: a survey of properties and processes. (M.Sc. thesis, University of Alaska, Fairbanks, AK.)

Liston, G. E. 1991. A computational model of two-phase, turbulent atmospheric boundary layers containing blowing snow. (Ph.D. thesis, Montana State University, Bozeman, MT.

Liston, G. E. 1995. Local advection of momentum, heat, and moisture during the melt of patchy snow covers. J. Appl. Meteorol., 34 (7), 1705-1715.

Liston, G. E., R. L. Brown and J. D. Dent. 1993a. Application of the $E-\epsilon$ 
turbulence closure model to separated atmospheric surface layer flows. Boundary-Layer Meteorol., 66 (3), 281-301.

Liston, G. E., R. L. Brown and J. D. Dent. 1993b. A two-dimensional computational model of turbulent atmospheric surface flows with drifting snow. Ann. Glaciol., 18, $281-286$.

Maeno, N. and 8 others. 1985. Wind-tunnel experiments on blowing snow. Ann. Glaciol., 6, $63-67$.

Male, D. H. 1980. The seasonal snowcover. In Colbeck, S. C., ed. Dynamics of snow and ice masses. New York, Academic Press, 305-395.

McKenna Neuman, C. and W. G. Nickling. 1994. Momentum extraction with saltation: implications for experimental evaluation of wind profile parameters. Boundary-Layer Meleorol., 68 (1-2), 35-50.

Mellor, M. 1965. Blowing snow. CRREL Monogr. III-A3c.

Murray, F.W. 1967. On the saturation vapor pressure. 7. Appl. Meteorol., 6 (1), 203-204.

Nägeli, W. 1971. Der wind als Standortsfaktor bei Aufforstungen in der subalpinen stufe. (Stillbergalp im Dischmatal, Kanton Graubünden). Mitt. Schweiz. Anst. Forstl. Vers'ies., 47, 33-147.

Owen, P.R. 1964. Saltation of uniform grains in air. 7. Fluid Mech., 20(2), $225-242$.

Pielke, R. A. and 10 others. 1992. A comprehensive meteorological modeling system - RAMS. Meteorol. Atmos. Phys., 49 (1-4), 69-91.

Pomeroy, J.W. 1988. Wind transport of snow. (Ph.D. thesis, Division of Hydrology, Faculty of Engineering, University of Saskatchewan, Saskatoon, Saskatchewan.

Pomeroy, J.W. 1989. A process-based model of snow drifting. Ann. Glaciol., $13,237-240$.

Pomeroy, J.W. and D. M. Gray. 1990. Saltation of snow. Water Resour. Res., $26(7), 1583-1594$.

Pomeroy, J.W. and D. M. Gray. 1995. Snowcover: accumulation, relocation and management. Saskatoon, Sask., Environment Canada. National Hydrology Research Institute. (NHRI Science Report 4.)

Pomeroy, J.W., D. M. Gray and P. G. Landine. 1993. The prairic blowing snow model: characteristics, validation, operation. J. Hydrol., $144(1-4)$, $165-192$.

Pomeroy, J.W. and D. H. Male. 1986. Physical modelling of blowing snow for agricultural production. In Steppuhn, H. and W. Nicholaichuk, eds. Proceedings of the Symposium, Snow Management for Agriculture, 1985, Swift Current, Saskatchewan. University of Nebraska, Lincoln, 73-108. Great Plains Agricultural Council Publication 120.

Pomeroy, J.W., P. Marsh and D. M. Gray. 1997. Application of a distributed blowing snow model to the Arctic. Hydrol. Processes, 11, 1451-1464.

Purves, R. S., J. S. Barton, W. A. Mackaness and D. E. Sugden. 1998. The development of a rule-based spatial model of wind transport and deposition of snow. Ann. Glaciol., 26, $196-202$.

Radok, U. 1977. Snow drift. J. Glaciol., 19 81), 123-139.

Ross, D. G., I. N. Smith, P. C. Manins and D. G. Fox. 1988. Diagnostic wind field modeling for complex terrain: model development and testing. . . Appl. Meteorol., 27 (7), $785-796$.

Ryan, B. C. 1977. A mathematical model for diagnosis and prediction of surface winds in mountainous terrain. 7. Appl. Meteorol., 16 6), 571-584.

Schmidt, R. A. 1980. Threshold wind-speeds and elastic impact in snow transport. J. Glaciol., 26 (94), 453-467.

Schmidt, R. A. 1982. Vertical profiles of wind speed, snow concentration and humidity in blowing snow. Boundary-Layer Meteorol., 23 2, 223-246.

Schmidt, R. A. 1986. Transport rate of drifting snow and the mean wind speed profile. Boundary-Layer Meleorol., 34 (3), 213-24l.

Schmidt, R. A. 1991. Sublimation of snow intercepted by an artificial conifer. Agric. Forest Meleorol., 54(1), 1-27.

Schmidt, R. A., Jr. 1972. Sublimation of wind-transported snow - a model. U.S. For. Serv. Res. Pap. RM-90.

Sherman, C. A. 1978. A mass-consistent model for wind fields over complex terrain. J. Appl. Meteorol., 17 (3), 312319.

Sundsbo, P.-A. 1997. Numerical modelling and simulation of snow drift. (Ph.D. thesis, Norwegian University of Science and Technology, Trondheim; Narvik Institute of Technology, Department of Building Science, Narvik.)

Tabler, R. D. 1975a. Estimating the transport and evaporation of blowing snow. In Snow Management on the Great Plains. Lincoln, NE, University of Nebraska, 85-105. (Great Plains Agricultural Council Publication 73.

Tabler, R. D. 1975b. Predicting profiles of snowdrifts in topographic catchments. Proc. West. Snow Conf., 43rd Annual Meeting, 23-25 April 1975, Coronado, California, 87-97.

Tabler, R. D. 1980. Geometry and density of drifts formed by snow fences. $\mathcal{f}$. Glaciol., 26 94), $405-419$.

Tabler, R. D. 1987. Slide rule for snow fence design. Proc. West. Snow Conf., 55th Annual Meeting, 14-16 April 1987, Vancouver, British Columbia, $162-165$.

Tabler, R. D., C. S. Benson, B.W. Santana and P. Ganguly. 1990. Estimating snow transport from wind speed records: estimates versus measurements at Prudhoe Bay, Alaska. Proc. West. Snow Conf., 58th Annual Meeting, 17-19 April 1990, Sacramento, California, 61-72.

Tabler, R. D. and R. L. Jairell. 1980. Studying snowdrifting problems with small-scale model outdoors. Proc. West. Snow Conf., 48th Annual Meeting, 15-17 April 1980, Laramie, Wyoming, 1-13.

Tabler, R. D. and R. A. Schmidt. 1986. Snow erosion, transport, and deposition in relation to agriculture. In Steppuhn, H. and W. Nicholaichuk, eds. Proceedings of the Symposium, Snow Management for Agricullure, 1985, Swift Current, Saskatchewan. Lincoln, University of Nebraska, 11-58. Great Plains Agricultural Council Publication 120.

Takeuchi, M. 1980. Vertical profile and horizontal increase of drift-snow transport. J. Glaciol., 26 94), $481-492$.

Thorpe, A. D. and B. J. Mason. 1966. The evaporation of ice spheres and ice crystals. 7. Appl. Phys., 17 (4), $541-548$.

Uematsu, T., T. Nakata, K. Takeuchi, Y. Arisawa and Y. Kaneda. 1991. Three-dimensional numerical simulation of snowdrift. Cold Reg. Sci. Technol., 20 (1), 65-73.

Wahrhaftig, C. 1965. Physiographic divisions of Alaska. L.S. Geol. Surt. Prof. Pap. 482.

Yoshino, M. M. 1975. Climate in a small area. Tokyo, University of Tokyo Press.

\section{APPENDIX}

The following sub-model has been implemented to quantify the sublimation mass transfer from the blowing and drifting snow to the atmosphere. The sublimation rate of windtransported snow, per horizontal unit area of snow cover, $Q_{\mathrm{v}}\left(\mathrm{kg} \mathrm{m}^{-2} \mathrm{~s}^{-1}\right)$, includes the contributions from both the saltating and turbulent-transport regimes. Separating the saltation layer contribution, between $z=0$ and $z=h_{*}$, where we have assumed the properties of the flow are constant with height, from the suspended-layer contribution, the general equation becomes

$$
Q_{\mathrm{v}}\left(x^{*}\right)=\Psi_{\mathrm{s}} \phi_{\mathrm{s}} h_{*}+\int_{h_{*}}^{z_{t}} \Psi_{\mathrm{t}}\left(x^{*}, z\right) \phi_{\mathrm{t}}\left(x^{*}, z\right) \mathrm{d} z
$$

where $\Psi_{\mathrm{s}}$ and $\Psi_{\mathrm{t}}\left(\mathrm{s}^{-1}\right)$ are the sublimation loss-rate coefficients for saltation and turbulent suspension, respectively; $\phi_{\mathrm{t}}\left(\mathrm{kg} \mathrm{m}^{-3}\right)$ is the vertical mass-concentration distribution in the turbulent-suspension layer; and the saltation-layer mass concentration, $\phi_{\mathrm{s}}\left(\mathrm{kg} \mathrm{m}^{-3}\right)$, is given by Equation (16). The solution of Equation (A-1) relies heavily on the previous work of Schmidt (1972, 1991), Pomeroy and others (1993) and Pomeroy and Gray (1995).

The sublimation-loss rate coefficient is given by

$$
\Psi\left(x^{*}, z\right)=\frac{\mathrm{d} \bar{m}(z) / \mathrm{d} t}{\bar{m}(z)}
$$

where $t(\mathrm{~s})$ is time and $\bar{m}(z)(\mathrm{kg})$ is the mean particle mass at height $z$. The mean particle mass is approximated as

$$
\bar{m}(z)=\frac{4}{3} \pi \rho_{\mathrm{i}} \bar{r}_{\mathrm{r}}(z)^{3}\left(1+\frac{3}{\alpha}+\frac{2}{\alpha^{2}}\right)
$$

where $\rho_{\mathrm{i}}\left(\mathrm{kg} \mathrm{m}^{-3}\right)$ is the density of ice and the mean radius of snow particles, $\bar{r}_{\mathrm{r}}(z)(\mathrm{m})$ at height $z$ is

$$
\bar{r}_{\mathrm{r}}(z)=4.6 \times 10^{-5} z^{-0.258}
$$

and the coefficient $\alpha$ is given by

$$
\alpha=4.08+12.6 z .
$$

The time rate of mass loss from an ice sphere is described by the combined influences of humidity gradients between 
the particle and atmosphere, intercepted solar radiation, particle size and advective (ventilation) influences, and is given by

$$
\frac{\mathrm{d} \bar{m}}{\mathrm{~d} t}=\frac{2 \pi \bar{r} \sigma-\frac{S_{\mathrm{p}}}{\lambda_{\mathrm{t}} T_{\mathrm{s}} \mathrm{Nu}_{\mathrm{u}}}\left[\frac{h_{\mathrm{s}} M}{R T_{\mathrm{a}}}-1\right]}{\frac{h_{\mathrm{s}}}{\lambda_{\mathrm{t}} T_{\mathrm{s}} \mathrm{Nu}_{\mathrm{u}}}\left[\frac{h_{\mathrm{s}} M}{R T_{\mathrm{a}}}-1\right]+\frac{1}{D \rho_{\mathrm{v}} \mathrm{Sh}}}
$$

where $M\left(18.01 \mathrm{~kg} \mathrm{kmole}^{-1}\right)$ is the molecular weight of water, $R$ (8313 $\mathrm{J} \mathrm{kmole}^{-1} \mathrm{~K}^{-1}$ ) is the universal gas constant, $T_{\mathrm{a}}(\mathrm{K})$ is the air temperature, $\lambda_{\mathrm{t}}\left(0.024 \mathrm{~J} \mathrm{~m}^{-1} \mathrm{~s}^{-1} \mathrm{~K}^{-1}\right)$ is the thermal conductivity of the atmosphere and $h_{\mathrm{s}}\left(2.838 \times 10^{6} \mathrm{~J} \mathrm{~kg}^{-1}\right)$ is the latent heat of sublimation (Thorpe and Mason, 1966; Schmidt, 1972). The diffusivity of water vapor in the atmosphere, $D\left(\mathrm{~m}^{2} \mathrm{~s}^{-1}\right)$, is given by (Thorpe and Mason, 1966)

$$
D=2.06 \times 10^{-5}\left(T_{\mathrm{a}} / 273\right)^{1.75}
$$

and the saturation density of water vapor, $\rho_{\mathrm{v}}\left(\mathrm{kg} \mathrm{m}^{-3}\right)$, at temperature $T_{\mathrm{a}}$, is (Fleagle and Businger, 1980)

$$
\rho_{\mathrm{v}}=0.622 \frac{e_{\mathrm{s}}}{R_{\mathrm{d}} T_{\mathrm{a}}}
$$

where $R_{\mathrm{d}}\left(287 \mathrm{~J} \mathrm{deg}^{-1} \mathrm{~kg}^{-1}\right.$ ) is the gas constant for dry air. The saturation vapor pressure over ice, $e_{\mathrm{s}}(\mathrm{Pa})$, is approximated by (Murray, 1967)

$$
e_{\mathrm{s}}=610.78 \exp \left(\frac{21.875\left(T_{\mathrm{a}}-273.16\right)}{\left(T_{\mathrm{a}}-7.66\right.}\right) \text {. }
$$

The radius of a snow particle, $\bar{r}(z)(\mathrm{m})$, of mean particle mass, $\bar{m}(z)$, is

$$
\bar{r}(z)=\left(\frac{3 \bar{m}(z)}{4 \pi \rho_{\mathrm{i}}}\right)^{\frac{1}{3}} .
$$

The vertical distribution of the atmospheric undersaturation of water vapor with respect to ice, $\sigma(z)$, is provided by a modification of an equation provided by Pomeroy and others (1993) and Déry and Taylor (1996) to describe the vertical variation of relative humidity from observations collected at $2 \mathrm{~m}$. The following equation allows application of relative humidity observations at other heights to determine $\sigma(z)$

$$
\sigma(z)=\sigma_{\mathrm{r}}(\Gamma+0.027 \ln (z))
$$

where $\sigma_{\mathrm{r}}$ is the undersaturation at the height of the relative humidity observations, $z_{\mathrm{rh}}(\mathrm{m})$,

$$
\sigma_{\mathrm{r}}=R H\left(z_{\mathrm{rh}}\right)-1
$$

where $R H$ is the relative humidity expressed as a fraction and $\Gamma$ is a relative-humidity offset defined by

$$
\Gamma=1-0.027 \ln \left(z_{\mathrm{rh}}\right) \text {. }
$$

The Nusselt and Sherwood numbers, Nu and Sh, are related to the particle Reynolds number (Re) (Lee, 1975)

$$
\mathrm{Nu}(z)=\operatorname{Sh}(z)=1.79+0.606 \operatorname{Re}(z)^{0.5}
$$
with

$$
\operatorname{Re}(z)=\frac{2 \bar{r}(z) V_{\mathrm{v}}(z)}{v}
$$

where $v\left(1.3 \times 10^{-5} \mathrm{~m}^{2} \mathrm{~s}^{-1}\right)$ is the kinematic viscosity of air and
$V_{v}\left(\mathrm{~ms}^{-1}\right)$ is the ventilation velocity. This velocity, $V_{v}$, is composed of a mean and a fluctuating velocity component, and for the case of turbulent suspension, $V_{\mathrm{v}}=V_{\mathrm{t}}$ has been modeled by Lee (1975) as

$$
V_{\mathrm{t}}(z)=\bar{w}(z)+3 x_{\mathrm{r}}(z) \cos \left(\frac{\pi}{4}\right)
$$

where the mean terminal-fall velocity of suspended snow, $\bar{w}(z)\left(\mathrm{m} \mathrm{s}^{-1}\right)$, is (Pomeroy and Male, 1986)

$$
\bar{w}(z)=1.1 \times 10^{7} \bar{r}(z)^{1.8}
$$

and the fluctuating velocity component has been given by Pomeroy (1988) for Prairie snow covers as

$$
x_{\mathrm{r}}(z)=0.005 u(z)^{1.36} .
$$

For the case of saltation, $V_{\mathrm{v}}=V_{\mathrm{s}}$, where $V_{\mathrm{s}}$ follows the formulation of Pomeroy and Gray (1995)

$$
V_{\mathrm{s}}=0.68 u_{*}+2.3 u_{* \mathrm{t}} .
$$

Under conditions of snow transport, the variation of air temperature, $T_{\mathrm{a}}$, with height is considered constant and equal to the observed air temperature.

The solar radiation absorbed by the snow particle, from above and below, $S_{\mathrm{p}}(\mathrm{W})$, is described by

$$
S_{\mathrm{p}}=\pi \bar{r}_{\mathrm{r}}(z)^{2}\left(1-\alpha_{\mathrm{p}}\right)\left(1+\alpha_{\mathrm{s}}\right) S_{\mathrm{i}}
$$

where $\alpha_{\mathrm{p}}$ is the snow-particle albedo, assumed to be 0.5 , and $\alpha_{\mathrm{s}}$ is the snow-cover surface albedo, assumed to be 0.8 (Schmidt, 1972). The incoming solar radiation which reaches the surface of the Earth, $S_{\mathrm{i}}\left(\mathrm{W} \mathrm{m}^{-2}\right)$, follows Liston (1995), and is given by

$$
S_{\mathrm{i}}=S^{*} \Upsilon \sin \omega
$$

where $S^{*}\left(1370 \mathrm{~W} \mathrm{~m}^{-2}\right)$ is the solar irradiance at the top of the atmosphere striking a surface normal to the solar beam, and $\Upsilon$ is the net sky transmissivity, or the fraction of solar radiation that makes it to the surface. The solar elevation angle, $\omega$, is defined as

$$
\sin \omega=\sin \delta \sin \eta+\cos \delta \cos \eta \cos \tau
$$

where $\eta$ is latitude, $\tau$ is the hour angle measured from local solar noon and $\delta$ is the solar declination angle approximated by

$$
\delta=\eta_{\mathrm{T}} \cos \left[2 \pi\left(\frac{d-d_{\mathrm{r}}}{d_{\mathrm{y}}}\right)\right]
$$

where $\eta_{\mathrm{T}}\left(23.45^{\circ} \mathrm{N}\right)$ is the latitude of the Tropic of Cancer, $d$ is the Gregorian Day, $d_{\mathrm{r}}$ (173) is the day of the summer solstice and $d_{y}(365.25)$ is the average number of days in a year (Duffie and Beckman, 1994).

To account for the scattering, absorption and reflection of shortwave radiation by clouds, the solar radiation is scaled according to

$$
\Upsilon=(0.6-0.2 \sin \omega)\left(1.0-0.5 \sigma_{\mathrm{c}}\right)
$$

where $\sigma_{\mathrm{c}}$ represents the fraction of cloud cover (Burridge and Gadd, 1974). 